ERC Working Papers in Economics 17/15

December / 2017

\title{
EDUCATION EFFECTS ON DAYS HOSPITALIZED AND DAYS OUT OF WORK BY GENDER: EVIDENCE FROM TURKEY
}

\author{
Aysit Tansel \\ Department of Economics, Middle East Technical University, Ankara, Turkey \\ Institute for the Study of Labor (IZA) Bonn, Germany \\ Economic Research Forum (ERF) Cairo, Egypt \\ E-mail: atansel@metu.edu.tr \\ Phone: + (90) 3122102073
}

\author{
Halil İbrahim Keskin \\ Department of Econometrics, Cukurova University, Adana, Turkey \\ E-mail: halil.keskin27@ gmail.com \\ Phone: + (90) 3223387254 - 156
}




\title{
EDUCATION EFFECTS ON DAYS HOSPITALIZED AND DAYS OUT OF WORK BY GENDER: EVIDENCE FROM TURKEY*
}

\author{
Aysit Tansel \\ Department of Economics \\ Middle East Technical University, Ankara, Turkey \\ E-mail: atansel@metu.edu.tr \\ Telephone: 90.312.210 2073 \\ Fax: +90.312.210 7957 \\ Institute for the Study of Labor (IZA) Bonn, Germany \\ Economic Research Forum (ERF) Cairo, Egypt \\ Halil Ibrahim Keskin \\ Department of Econometrics \\ Cukurova University, Saricam, Adana, Turkey \\ E-mail: halil.keskin27@gmail.com \\ Telephone: +90.322.338 72 54- 156
}

December 8, 2017

\begin{abstract}
The strong relationship between various health indicators and education is widely documented. However, the studies that investigate the nature of causality between these variables became available only recently and provide evidence mostly from developed countries. We add to this literature by studying the causal effect of education on days hospitalized and days out of work for health reasons. We consider two educational reforms. One is the educational expansion of the early 1960s and the other is the 1997 increase in compulsory level of schooling from five to eight years. However, due to the possibility of weak instruments we do not further pursue this avenue. We focus on individuals in two cohorts namely, 1945-1965 which is an older cohort and 1980-1980 which is a younger cohort. We estimate Tobit models as well as Double Hurdle models. The results suggest that an increase in years of education causes to reduce the number of days hospitalized for both men and women unambiguously and the number of days out of work only for men while an increase in education increases the number of days out of work for a randomly selected women.
\end{abstract}

JEL: I15, I26, J16, J18, C34, C36

Keywords: Education, Days hospitalized, Days out of work, Education reform, Tobit model, Double Hurdle model, Gender, Turkey.

- This research is supported by the Economic Research Forum (ERF) in collaboration with the MENA Health Policy Forum (MENA HPF) on "Economics of Healthcare in the ERF Region”. The contents and recommendations do not necessarily reflect the views of the Economic Research Forum. We are grateful to an anonymous referee of the ERF for insightful comments on an earlier version of this paper which helped to improve the paper substantially. 


\section{1) Introduction}

Education and health are the two most important forms of human capital. Their value stems from the observation that they both make individuals more productive. There is a large literature on the productivity effects of education. See for instance Schultz (1989) and Psacharopoulos and Patrinos (2004). There is equally a large literature on the productivity effects of good health. See for instance Schultz (1997; 2005); Schultz and Tansel (1997); Thomas and Strauss (1997). At the macro-level it is well documented both theoretically and empirically that education is an important determinant of economic growth. See for instance Bils and Klenow (2000). A number of studies provide evidence that good health contributes to economic growth and morbidity adversely affects economic growth and national well-being. See for instance Deaton (2003); Mwabu (2003) and Weil (2007). Further, both education and health significantly contribute to individual well-being in terms of both job satisfaction (see for instance Gazioğlu and Tansel, 2006) and life satisfaction ( see for instance Palmore and Luikart (1972)).

Another area of research is the mutual relation between these two important forms of human capital namely education and health. Grossman and Kaester (1997) and Grossman (2003) both provide a comprehensive overview of the empirical works on the relation between education and health. A number of studies show that there is a significantly strong and positive association between education and health (see for instance, Arendt, 2005; Behrman and Wolfe, 1989; Berger and Leigh 1989; Gilleskie and Harrison 1998; Hartog and Oosterbeck, 1998; Kenkel, 1991; 1995; Leigh, 1998; Adams 2001; Spasojevic, 2003).

The focus of this article is the relation between education and health. We ask the question if education improves health. The robust relationship between education and health is widely documented. There are a number of studies that demonstrate the correlation between education and health. However, it is more important to establish the causal nature of this relationship. This is important not only for the intrinsic value of knowing whether education has a causal effect on health but also from the point of view of social policy. For instance, if education causally affects health then a shift of public attention and funds from health care to education can advance both educational attainment and the health standing in any society. The direction of causality between education and health is studied less often and only recently and mostly in developed countries. Evidence from developing countries is scanty. Therefore, this study will investigate the causal effect of education on health in Turkey a middle income, developing country. There are two measures of health that we will consider. They are days hospitalized and days out of work as reported by the individual. It is well known that self-reported health measures are subjective and plagued with measurement errors (Butter, Burkhauser Mitchell and Pincus, 1987; Kreider, 1999; Lindeboom and Kerkhofs, 2002). However, the health measures we consider in this study could be less problematic in this respect. 
Recent studies in this topic considered mainly the case of developed countries such as the USA (Berger and Leigh, 1989), Sweden (Spasojevic, 2003) or Denmark (Arendt, 2008). There is less evidence from the developing countries. As a developing middle-income country Turkey will be an interesting case to study the nature of the relationship between education and health. Recently, there have been marked declines in adult mortality and morbidity as well as improvements in the nutritional front in Turkey. Tansel $(2002 ; 2012)$ review the recent developments in the health status of the population and health system in Turkey.

The two health outcomes we consider are number days hospitalized and number of days out of work for health reasons. We consider two recent educational reforms as the source of exogenous variation in education. One is the educational expansion of the early 1960s and the other is the 1997 increase in compulsory level of schooling from five to eight years. However, our instrumental variable estimates are not reliable due to possibility of weak instruments and we abandon this approach. We focus on individuals in two cohorts namely, 1945-1965 which is an older cohort and 19801980 which is a younger cohort. We estimate and present Tobit models as well as Double Hurdle models. The econometric methodology employed considers the fact that the dependent variables, days hospitalized and days out of work both contain substantial number of zero days. Such an approach has not been used to analyze days hospitalized and days out of work in the Turkish case. The results suggest that an increase in years of education causes to reduce the number of days hospitalized for both men and women unambiguously and the number of days out of work only for men while an increase in education causes an increase the number of days out of work for a randomly selected women. We elaborate on the possible reasons for these results. The results provide interesting insights.

\section{2) Brief Review of Literature}

Grossman and Kaestner (1997) and Grossman (2000; 2003) both provide excellent review of the empirical literature on the relation between education and health. Early empirical work reported merely on the association between education and health. Recent studies sought to identify the causal impact of education on health. For this purpose they used IV estimation strategies with various instruments where education is treated endogenous to health. Grossman (1975) controlled for health in childhood for identification. Behrman and Wolfe (1989) aimed to remove common family effects using data on siblings. Berger and Leigh (1989) used educational expenditures in the state of birth, parental education and income as instruments for education. Arkes (2002) used differences in unemployment rates between states as instrument for education. Adams (2001) used quarter of birth in the USA. More recently the use of such instruments are criticized and the recent studies used instruments related to school reforms. Tansel and Karaoglan (2016) in Turkey and Spasojevic (2003) in Sweden used school reforms. Similarly, Arendt $(2005 ; 2008)$ in Denmark and Lleras-Munay (2005) in the USA also used school reforms to identify exogenous variation in education. There are other studies on the relation between education and health. These further studies include but not limited to the following. 
Kenkel (1991; 1995), Gilleskie and Harrison (1998), Hartog and Oosterbeek (1998), Leigh (1998), Cowell (2006), Cutler and Lleras-Muney (2006), Silles (2009), Conti, Heckman and Urzua (2010), Lundborg, Nilsson and Rooth (2016).

\section{3) Conceptual Framework and the Model}

There are several arguments that are proposed to explain the positive correlation between education and health. According to the productive efficiency argument more educated people obtain better health outcomes from given quantitates of health inputs ( Grossman, 1972, 2000). In other words, highly educated people produce health more efficiently, implying that higher education leads to improved health. More clearly the notion of efficiency means that the more education one has the more health one can obtain out of a given dose of hospital days which is one of our health measure in this paper. The cognitive ability can make one more productive and reduce the hospital days by showing nursing staff ability to learn how to take medications, change dressings adhere to new diet etc. On the other hand, allocative efficiency argument emphasizes the selection of health inputs. Since, education improves an individual's knowledge about health, then highly educated are better able to select healthy lifestyles and best health inputs. Further educated people implement faster the new heath information. Finally, education leads to higher incomes which enables purchase of better health inputs.

Simple estimation of the effect of education from regression of heath on education may not be causal due to several factors. This argument points to the two-way causality between education and health. In other words, there is causality from better health to more education in addition to causality from education to health. Several researchers more recently Case et al. $(2002 ; 2003)$ demonstrated that childhood circumstances are important determinants of both the adult health and educational attainment. As a result, because of the importance of past health, healthier people learn more efficiently and are more likely to attend school longer. A second argument proposes that omitted third variables could affect both the amount of education attained and the state of health. One such omitted variable is the time preference. (Farrell and Fuchs, 1982; Fuchs, 1982). Fuchs (1982) explained that preference for present versus future may be important in determination of heath investments and behaviors. For instance, future-oriented people place higher value on future benefits of both the education and health. Therefore, they invest more both in better health practices and greater education. Finally, genetically inherited traits may play a vital role in adult health. There may be differential heath endowments and differential school ability.

The education and health relationship can be presented by following twoequation model.

$$
\begin{aligned}
& \text { Health }=\alpha_{1} \text { Education }+X \alpha_{2}+e_{1} \\
& \text { Education }=\beta_{1} Z+X \beta_{2}+e_{2}
\end{aligned}
$$


In the first equation, the coefficient $\alpha_{1}$ represents the causal effect of education on health. The vector $\mathrm{X}$ presents the common determinants of both education and health. They may include variables representing age, cohort effects, family background characteristics and geographical regions. The unobserved disturbance terms are shown as $e_{1}$ and $e_{2}$ respectively in the health and education equations. If $\mathrm{e}_{1}$ and $\mathrm{e}_{2}$ are correlated then schooling will be correlated with $\mathrm{e}_{1}$ violating one of the main assumptions of Ordinary Least Squares (OLS) estimation. Therefore, application of OLS to the first equation will produce biased and inconsistent estimates of the coefficients. Inclusion of the education equation and the vector of variables $\mathrm{Z}$ allow estimation of the health equation and the coefficient $\alpha_{1}$ by the Instrumental Variable (IV) method. The vector $\mathrm{Z}$ must include variables that are highly correlated with education (instrument relevance) but are uncorrelated with the unobservable variables in the health equation which are subsumed in $\mathrm{e}_{1}$ (instrument exogeneity) . The IV method involves a two-stage estimation. In the first stage education equation is estimated. In the second stage health equation is estimated using predicted education from the first stage in place of the actual education.

\section{4) The Data}

This study uses the Turkish Health Survey (THS) collected by the Turkish Statistical Institute (TURKSTAT). There are several waves of this survey available. Therefore, this study will use and pool the waves of 2008, 2010, 2012, and 2014. Each survey is a nationally representative random sample of about ten to fifteen thousand individuals. This survey is also used to analyze health behaviors by Tansel and Karaoglan (2014). The survey includes information on a number of individual and personal characteristics including age, sex, education, employment and household income. Separate questionnaires are applied to the 0-6 age group, 7-14 age group and 15 and over age group in terms of health related issues. We will use the section of the questionnaire for the 15 and over age group. There are a number of self-reported health assessments including daily functional limitations and limitations in personal

care. Further information includes utilization of health services, pharmaceuticals and utilization of various preventive measures such as vaccinations and various health related tests. In this questionnaire a separate section considers the various questions on health related behaviors and lifestyles such as smoking, drinking and others. There are also questions on various diseases.

We will consider two health outcomes in this study. The first health outcome considered is related to hospitalization which is asked to all individuals. There are two related questions. The first question (Question no 66) asks: Were you hospitalized at all with at least one overnight stay during the last 12 months? The second question (Question No. 68) asks: Considering all of your hospitalizations how many nights did you spend in the hospitals during the last 12 months? We will use this health measure in continuous form as number of days hospitalized. The first question is utilized to estimate the probit specification. 
The second health outcome we consider in this study is the days out of the work which is asked to people who are currently employed. This health outcome is previously used by Schultz and Tansel (1997) in Cote D'Ivoire and Ghana. There are two related questions. The first question (Question No. 11) asks: Did you take time off from your work due to a health problem during the last 12 months. The second question (Question No. 12) asks: How many days did you take off from your work due to the health problems during the last 12 months. We will use this health measure in the continuous form. The first question will be utilized to estimate the probit specification. Further, in the 2010 wave we do not know the labor market status of the individuals. Therefore, 2010 wave is omitted in Table 2 but not in analysis days out of work for all employed individuals which include wage-earners, self-employed, employer and unpaid family workers.

All hospitalizations are mostly at public hospitals where costs are covered by the state. Recently the number of private hospitals increased tremendously in Turkey as well as their utilization. The recent health insurance system partly covers the costs at the private hospitals for which there is a co-payment.

For women the days hospitalized or the days out of work both exclude the relevant days due to pregnancy and child birth. For the samples of days out of work we have eliminated the upper 0.33 percent of observations for women and the upper 0.32 percent of observations for men as outliers. These amounted to deleting 71 observations for women and 56 observations for men. This corresponded to eliminating observations with 120 days and over for women and 200 days and over for men from the samples of days out of work.

\subsection{Hospitalization as a Health Outcome}

Hospitalization is obscure in nature and could signify three possible meanings. First of all, it could indicate demand for health care. This aspect is elaborated by Cameron et al. (1988) and Riphahn et al. (2003). Thus, one could see days hospitalized as a measure of health input. How much of this health input is used depends on the individuals demand for health, prior stock of health capital and access to substitute health inputs. Second, as remarked by Geil et al. (1997) hospitalization could suggest poor health status. Third, hospitalization could reflect the supply of hospitals and their accessibility. For these reasons, the effect of education on the number of days hospitalized could be due to all these three factors namely, demand for health care, poor health status and supply of hospitals. In practice these effects can be very difficult to distinguish from one another and this will not be attempted in this paper. It is not possible to tell which effect dominates the others a priory. However, we are interested in hospitalization to represent poor health status.

A typical hospital stay has usually three phases such as a beginning, a middle and an end. During the beginning phase there is high intensity technical inputs. They are utilized to make a diagnosis and select a treatment course. During the middle phase nursing staff carries out most of the work by checking vital signs and giving 
intravenous treatments. During the end phase there is a process of teaching the patient and family about how to manage the case at home. This process may involve additional outpatient medications, diets and new behaviors. It is quite typical for patients and their families to hasten the end of the hospital stay by showing their capability to learn the new outpatient regimen during the middle and end of the stay.

Disease severity can lengthen the hospital stay that is, increase the number of days hospitalized. This may be due to medical staff taking longer to reach a diagnosis in the beginning phase. Further, recovery may require longer time during the middle phase of the hospital stay. Therefore, the length of the stay that is, the number of days hospitalized could be a mixed indicator of disease severity, demand for health care and presence of substitution possibilities.

We postulate that theoretically education might lead to fewer hospital days. This is because education can have Grossman (1972) effects on the demand for health care which lead to complete prevention of the need for hospitalization as well as lower disease severity. In addition, we assert that conditional on hospitalization, education will offer the patient higher ability to learn how to self-care and hasten the end of their stay thus, leading to fewer hospital days.

It is more likely that hospitalization indicates poor health status in the Turkish case rather than being a measure of health input or denoting supply or the access to hospitals. This is because of the recent universal health insurance reform which covers our sample period. As remarked earlier, health care in public hospitals are free of charge while in private hospitals it involves a co-payment. This implies that the supply of hospitals and their accessibility is not a major impediment for their utilization. Hospitalization could be seen as a demand for health care however, the demand for health care will not develop unless one has poor health status. Therefore, in this study we will consider days hospitalized as a good measure of a person's health status.

\section{5) Empirical Specification}

This research will estimate the causal effect of education on health. The analysis will be carried out separately for men and women. For this purpose the 2008, 2010, 2012 and 2014 waves of the THS conducted by the TURKSTAT will be used. The measurement error in health status that is systematically correlated with one or more explanatory variables, measurement error in education, endogeneity of education, omitted variables and health heterogeneity are the main estimation problems and result in biased and inconsistent estimates. Essentially the endogeneity of education is really a form of unobservable confounding due to a childhood health endowment. This childhood health endowment presumably leads simultaneously to choice of schooling attainment and then lingers to adulthood to offer health capital effects that can affect the health status more clearly that can keep them out of the hospital and make them recover sooner. In order to obtain consistent estimates, the problems of omitted variables, errors in variables and reverse causality will be surmounted within the 
framework of IV estimation. There are two health outcomes that will be used in this study. They are number of days hospitalized and number of days out of work. They are considered both as a continuous outcome. Education variable is also considered as a continuous variable measuring the years of schooling completed. This will allow comparisons with previous studies.

In the IV estimation procedure it is important to find suitable instruments that are highly correlated with education but not correlated with unobservables that affect the health status. The first condition is referred to as instrument relevance and the second condition is referred to as instrument exogeneity. In this study two educational reforms implemented during the study period will be used to identify the education effects on days hospitalized and days out of work. One is the educational expansion of the early 1960's. The other is the 1997 extension of the compulsory schooling level from five to eight years. In several previous studies both of these educational reforms are shown to be valid instruments for education. Tansel and Karaoglan (2016) used educational expansion of the early 1960's as an instrument. Kirdar, Dayioglu and Koc (2012) and several other researchers used the 1997 extension of the compulsory schooling as an instrument successfully. This study will use these two school reforms as instruments individually. The educational expansion of the early 1960's will be used for the older cohort (1945-1965) of individuals. The 1997 extension of the compulsory schooling level will be used for the younger cohort (1980-1990) of individuals. This will allow us to check for the robustness of the results. Tests for the validity and relevance of the instruments are performed.

Figure 4 presents a plot of alternative measures of schooling versus year born for the two educational reforms in to visually determine if they actually had effects on schooling. The left hand side graphs refer to the 1961 Education reform for the cohort of 1945-1965. The vertical lines indicate the birth year of 1952 which marks the cohorts that are influenced by the educational expansion of the early 1960's. The right hand side graphs refer to the 1997 Education Reform for the cohort of 1980-1990. The vertical lines indicate the birth year of 1982 which marks the cohorts that are influenced by the extension of the compulsory schooling level from five to eight years. In the top panel the schooling measure is average years of schooling. In the middle panel on the left hand side the schooling measure is the fraction of the sample at least primary school (five years) educated. In the middle panel on the right hand side the schooling measure is the fraction of the sample at least middle school (eight years) educated. In all of the cases, we observe an increase in the alternative measures of schooling for the cohorts influenced by the two Education Reforms which is more evident on the right hand side figures for the reform of 1997.

We limit our analysis to specific cohorts who are enrolled in school several years before and several years after the affected cohort by the Reform considered. More clearly for the 1961 reform we limit the sample to those who were born between 19451965. For the 1997 reform we limit the sample to those who were born between 19801990. This will allow us to see the education effects on an older cohort with the former sample and a younger cohort with the latter sample. The older cohort will be between 
43-69 years of age during the survey years and the younger cohort will be between 1834 years of age during the survey years used in this study.

\section{1) Tobit Model}

For a substantial number of observations we observe zero days hospitalized and zero days out of work. Therefore we specify a Tobit model due to Tobin (1958) as follows.

$$
\begin{aligned}
& y^{*}=\beta_{0}+\beta_{1} x+u \\
& y=y^{*} \text { if } y^{*}>0 \\
& y=0 \quad \text { otherwise } \\
& u \sim \mathrm{N}\left(0, \sigma^{2}\right)
\end{aligned}
$$

Where $\mathrm{y}^{*}$ is the latent variable and $\mathrm{y}$ is the actual days observed. Each individual has a latent or unobserved days. If it is known it is given the actual days and if it is unknown it is denoted by zero. $x$ represents the explanatory variables. $y$ is constrained and there is clustering around zero. This violates a basic assumption of OLS. OLS on the complete sample is biased and inconsistent. OLS on the un-clustered part is also biased and inconsistent Therefore, we estimate a Tobit model with maximum likelihood estimation procedure. The likelihood function is given by:

$$
f\left(y \mid x_{1}\right)=\left\{1-\Phi\left(\boldsymbol{x}_{1} \boldsymbol{\beta} / \sigma\right)\right\}^{1(y=0)}\left[(2 \pi)^{-\frac{1}{2}} \sigma^{-1} \exp \left\{-\left(y-\boldsymbol{x}_{1} \boldsymbol{\beta}\right)^{2} / 2 \sigma^{2}\right\}\right]^{1(y>0)}
$$

There are several expected values and the corresponding marginal effects in the Tobit model as it is shown by McDonald and Moffitt (1980). Two of the more interesting ones are the expected value conditional on a positive observation on $y$ and the expected value for a randomly selected observation. They are given as follows:

$$
\begin{aligned}
& E(y \mid y>0, x)=\beta_{0}+\beta_{1} x+\lambda\left(\frac{\beta_{0}+\beta_{1} x}{\sigma}\right) \\
& E(y \mid x)=\Phi\left(\frac{\beta_{0}+\beta_{1} x}{\sigma}\right)\left[\beta_{0}+\beta_{1} x+\lambda\left(\frac{\beta_{0}+\beta_{1} x}{\sigma}\right)\right]
\end{aligned}
$$

Where

$$
\lambda(c) \equiv \varphi(c) / \Phi(c)
$$

The corresponding marginal effects are given by the following formulas which will be used in the estimation in this paper:

$$
\frac{\partial E(y \mid y>0, x)}{\partial x}=\beta_{1}\left\{1-\lambda\left(\frac{\beta_{0}+\beta_{1} x}{\sigma}\right)\left[\frac{\beta_{0}+\beta_{1} x}{\sigma}+\lambda\left(\frac{\beta_{0}+\beta_{1} x}{\sigma}\right)\right]\right\}
$$




$$
\frac{\partial E(y \mid x)}{\partial x}=\beta_{1} \Phi\left(\frac{\beta_{0}+\beta_{1} x}{\sigma}\right)
$$

\section{2) Double Hurdle Model}

In the Tobit model there is only one decision. Double Hurdle model which is due to Cragg (1971) is a popular generalization of the Tobit model ( see also Jones, 1989 and Pudney, 1989). The Double Hurdle model is popularly used to estimate a number of different household expenditure items where zero expenditure observations are common. For example, Humphreys et al. (2010) and Crowley et al. (2012) analyzed household lottery expenditures and Aristei and Pieroni (2008) analyzed household tobacco expenditures. In the Double Hurdle model individuals go through two separate hurdles. The first hurdle is the participation decision which in our case decision to hospitalize or opt out of work. The second hurdle is the intensity decision which in our case how many days to be hospitalized or how many days to stay out of work. Actually both decisions depend on the severity of sickness. The first decision is a probit model with $\mathrm{w}^{*}$ as the binary latent variable and the second decision is essentially a censored model with $\mathrm{y}^{*}$ as a different latent variable ${ }^{1}$. In the Tobit model both decisions are basically the same. However in the decision process there may be time and monetary costs, information cost and a search process. For these reasons, in the case of hospitalization and out of work cases Double Hurdle model may be more appropriate to use than the Tobit model. We specify the Double Hurdle model as follows.

$$
\begin{array}{ll}
w_{i}^{*}=x_{1 i} \gamma+u_{i} & \text { participation decision } \\
y_{i}^{*}=x_{2 i} \beta+v_{i} & \text { intensity decision } \\
y_{i}=x_{i} \beta+v_{i} & \text { if } w_{i}^{*}>0 \text { and } y_{i}^{*}>0 \\
y_{i}=0 & \text { otherwise }
\end{array}
$$

where $\mathrm{w}^{*}$ is the binary latent variable indicating the decision to hospitalize or the decision to opt out of work; $\mathrm{y}^{*}$ is the latent continuous variable indicating the number of days hospitalized or the number of days out of work; x's are explanatory variables. In addition to normality the Double Hurdle model also assumes conditional independence of the latent variable's distribution. This model is estimated with maximum likelihood methods. The

1 In the censored econometric models the dependent variable is not fully observed but, independent variables such as individual characteristics are observed. The truncated data model is a situation where a subset of the population is observed. That is, both the dependent and the independent variables are not observed for a subset of the population. 
presentation below follows the discussion in Burke (2009). The likelihood function is as follows:

$$
\begin{gathered}
f\left(w, y \mid \boldsymbol{x}_{1}, \boldsymbol{x}_{2}\right)=\left\{1-\Phi\left(\boldsymbol{x}_{1} \boldsymbol{\gamma}\right)\right\}^{1(w=0)}\left[\Phi\left(\boldsymbol{x}_{1} \boldsymbol{\gamma}\right)(2 \pi)^{-\frac{1}{2}} \sigma^{-1}\right. \\
\left.\exp \left\{-\left(y-\boldsymbol{x}_{2} \boldsymbol{\beta}\right)^{2} / 2 \sigma^{2}\right\} / \Phi\left(\boldsymbol{x}_{2} \boldsymbol{\beta} / \sigma\right)\right]^{1(w=1)}
\end{gathered}
$$

The expected value of y conditional on y being positive:

$$
E\left(y_{i} \mid y_{i}>0, \boldsymbol{x}_{2 i}\right)=\boldsymbol{x}_{2 i} \boldsymbol{\beta}+\sigma \times \lambda\left(\boldsymbol{x}_{2 i} \boldsymbol{\beta} / \sigma\right)
$$

where lambda is the Inverse Mills Ratio given by:

$$
\lambda(c)=\phi(c) / \Phi(c)
$$

The unconditional expected value of y for a randomly selected observation is:

$$
E\left(y_{i} \mid \boldsymbol{x}_{1 i}, \boldsymbol{x}_{2 i}\right)=\Phi\left(\boldsymbol{x}_{1 i} \boldsymbol{\gamma}\right)\left\{\boldsymbol{x}_{2 i} \boldsymbol{\beta}+\sigma \times \lambda\left(\boldsymbol{x}_{2 i} \boldsymbol{\beta} / \sigma\right)\right\}
$$

The probability that $\mathrm{y}$ is positive is given by:

$$
P\left(y_{i}>0 \mid x_{1 i}\right)=\Phi\left(x_{1 i} \gamma\right)
$$

The marginal effect of an independent variable, $x_{j}$, around the probability that $\mathrm{y}$ is positive is given by:

$$
\frac{\partial P\left(y>0 \mid x_{1}\right)}{\partial x_{j}}=\gamma_{j} \phi\left(x_{1} \gamma\right)
$$

The last two expressions are the same as the probabilities and the marginal effect from the probit regression of $\mathrm{w}$ on $\mathrm{x}$.

The corresponding marginal effects to the preceding expected values as the conditional marginal effect is as follows:

$$
\frac{\partial E\left(y_{i} \mid y_{i}>0, \boldsymbol{x}_{2 i}\right)}{\partial x_{j}}=\beta_{j}\left[1-\lambda\left(\boldsymbol{x}_{2} \boldsymbol{\beta} / \sigma\right)\left\{\boldsymbol{x}_{2} \boldsymbol{\beta} / \sigma+\lambda\left(\boldsymbol{x}_{2} \boldsymbol{\beta} / \sigma\right)\right\}\right]
$$

and the unconditional margial effect is as follows:

$$
\begin{aligned}
\frac{\partial E\left(y \mid \boldsymbol{x}_{1}, \boldsymbol{x}_{2}\right)}{\partial x_{j}} & =\gamma_{j} \phi\left(\boldsymbol{x}_{1} \gamma\right) \times\left\{\boldsymbol{x}_{2} \boldsymbol{\beta}+\sigma \times \lambda\left(\boldsymbol{x}_{2} \boldsymbol{\beta} / \sigma\right)\right\} \\
& +\Phi\left(\boldsymbol{x}_{1} \boldsymbol{\gamma}\right) \times \boldsymbol{\beta}_{j}\left[1-\lambda\left(\boldsymbol{x}_{2} \boldsymbol{\beta} / \sigma\right)\left\{\boldsymbol{x}_{2} \boldsymbol{\beta} / \sigma+\lambda\left(\boldsymbol{x}_{2} \boldsymbol{\beta} / \sigma\right)\right\}\right] \text { if } x_{j} \epsilon \boldsymbol{x}_{1}, \boldsymbol{x}_{2}
\end{aligned}
$$

If $\mathrm{xj}$ is included only in $\mathrm{x} 1$ (first hurdle) then betaj will be zero then the second expression in the above formula will disappear. If $\mathrm{xj}$ is included only in $\mathrm{x} 2$ (second hurdle) gammaj will be zero then the first expression in the above formula will disappear. 


\section{6) Empirical Results}

\section{1) Descriptive Statistics}

The figures and the descriptive statistics tables discussed in this section are based on the total samples of 18-69 years of age. The lower age limit is based on the observation that for individuals younger than 18, hospitalization is the parental decision.

Figure 1 gives the distribution for days hospitalized for the total sample of age 1869 years. Figure 2 gives the distribution of the days out of work for wage-earners. Figure 3 gives the distribution of days out of work for the self-employed. Actually, for days out of work, we planned to examine the wage-earners and the self-employed samples separately. However, this was not possible due to very small number of observations with non-zero outcomes in these subsamples of workers. In both the days hospitalized and the days out of work observations with zero days are substantial with over 80 percent as it is shown in Figures 1, 2 and 3 by gender.

Tables 1 and 2 give the characteristics by gender of the samples of zero observations and positive observations for days hospitalized and days out of work respectively. We can interpret the zero days as an indicator of good health both for the days hospitalized and for the days out of work. In both tables the last column gives pvalues for the test of the hypothesis that the means are equal between the zero-day and non-zero day groups. In Table 1 we reject the null hypothesis that the means for various characteristics for the zero-day and non-zero days of hospitalization are the same in all cases for the female and male samples at 1 percent level except for the category of university and above educated in the case of females. We conclude that for both females and males the characteristics for the zero-day group and the non-zero day group are substantially different from each other except the university and above characteristic for females. Table 2 shows the characteristics for zero and non-zero days out of work. In the case of females all characteristics are significantly different from one another for the zero and non-zero days. In the case of males all characteristics are significantly different from one another at one percent level with three exceptions. The high school education is different at 5 percent level and at least middle school and primary and less categories are not statistically significantly different from one another for the zero and non-zero day groups.

Table 1 shows that for the females with positive days the mean days hospitalized is about 6 days. The females with positive days hospitalized are somewhat older (41 years of age) than those with zero days (38 years of age). The females with positive days of hospitalization have about 6 years of education and those with zero days of hospitalization have about 7 years. Their educational distributions are statistically significantly different except at the university and above category where the zero day and non-zero day groups of females have similar proportions. We now compare the males. For males with positive days the mean days 
hospitalized is about 8 days which is two days larger than that of females. The males with positive days hospitalized are somewhat older (45 years of age) than those with zero days (38 years of age). The years of education and the rest of the educational distribution are statistically significantly different from one another for the zero and non-zero days groups.

Table 2 shows the various characteristics for the two groups of zero and non-zero days out of work. For the females the mean days out of work is about 15 days. The females with positive days out of work are somewhat younger (36 years of age) than those with zero days (39 years of age). Further females with positive days out of work are substantially better educated than those with zero days out of work. More clearly, those with positive days out of work have about 10 years of education and those with zero days out of work have about 6 years of education. The educational distributions of these two groups indicate that those with positive days out of work are 33 percent university educated and those with zero days out of work are about 8 percent university educated. These signify that those females with non-zero days out of work are substantially better educated than those with zero days out of work. We now consider the male sample. Mean days out of work is about 21 days which is longer than that of females. The males with positive days out of work are better educated (with about 9 years) than those with zero days out of work (with about 8 years of education). Those males with positive days out of work are 17 percent university and above educated and those with zero days out of work are about 14 percent university and above educated. Those with high school educated are different from one another at 5 percent level of significance. However, those with at least middle school education and those with primary school or less education are not statistically significantly different from one another for the two groups of zero and non-zero days.

In summary we can say that while females with positive days hospitalized during the last 12 months are substantially older but, they are less educated than those who are never hospitalized during the past year. The males with positive days hospitalized are also older but less educated than those who are never hospitalized during the past year. In contrast, females with positive days out of work are somewhat younger but are substantially better educated than those females who are never hospitalized during the past year. The males with positive days out of work are somewhat younger but better educated than those who are never out of work during the past year.

Table 3 reports the average number of days hospitalized in the last year by gender, age, education and employment status. For all younger (older) females the average number of days hospitalized (clearly falls as education increases) first falls as education increases from primary or less to middle school but stays about the same as education increases further. For all younger and older males the average number of days hospitalized clearly fall as education increases. For both all females and males the average number of days hospitalized is larger for the older than for the younger. For the younger wage-earner females the average number of days hospitalized stays about the same (except the spike at middle school) as education increases. For the older wage-earner females, younger and older wage-earner males the average number 
of days hospitalized clearly decline as education increases. Similar to the case of all females and males the average number of days hospitalized is larger for the older than for the younger. For the younger and older female self-employed, there is no obvious pattern for the average number of days hospitalized. For the male self-employed the average number of days hospitalized decrease both for the younger and the older groups except the dip in the middle school for the younger group. Again, the average number of days hospitalized is larger for the older than for the younger.

Table 4 reports the average number of days out of work in the last year by gender, age, education and employment status. For all of the groups there is no clear pattern of the average number of days out of work except for the younger male wageearner at which the average number of days out of work declines as education increases. At all education levels the average number of days out of work is larger for the younger than for the older groups except for the all males and male selfemployed.

\section{2) Estimation Results}

In this section we report the IV-Tobit, Tobit and Double Hurdle estimation results. The first stage OLS estimates of the education equation by gender are given in Table 5. As mentioned previously, there are two instruments used in this study. One is the educational expansion of early 1960's. The other is the compulsory education extension from five to eight years in 1997. The first stage estimation is OLS regression of "years of schooling" on either educational reform of 1961 (PD1961) or educational reform of 1997 (PD1997). Both are dummy variables. The "Reform 1961" takes a value of 1 from 1952 onwards and zero before. Students may start school either at 6 or at 7 years of age. Because of this fuzziness we exclude the year 1952. The "Reform 1997 " takes the value of one from 1986 onwards and zero before. Again the students may start school either at 6 or at 7 years of age. Because of this fuzziness we exclude the year 1986. Table 5 reports the coefficients of the reform dummies by gender. We observe that in the sample of days hospitalized for the cohort of 1945-1965 the coefficient of the Reform 1961 is negative and insignificant for females but positive and significant for males while the coefficients of the Reform 1997 are both positive and significant. In the samples of days out of work for the cohort of 1945-1965 the coefficient of the Reform 1961 is negative and insignificant for females but positive and significant for males while the coefficients of the Reform 1997 are both positive and significant. Therefore except in the cases of the Reform 1961 for females both of the reform dummies are positive and statistically significant. However, both of the reform dummies are rather weak instruments since they do not pass the Stock and Yogo (2005) criterion of a t-statistic larger than 3.2 for a strong instrument. For this reason, our IV-Tobit estimates as well as the accompanying exogeneity test of the education variable that are presented in the next section are not reliable 


\section{Tobit Model Estimates}

Table 6 reports the results for IV-Tobit and Tobit estimates. At the lower part of the table, we report the results for Wald test of exogeneity of education, the instrumented variable. This test result indicates that in all cases the test statistic is not significant. This indicates that there is not sufficient information in the sample to reject the null hypothesis of exogeneity. Therefore these test results indicate that Tobit estimates are valid rather than the IV-Tobit results. However, this test may not be reliable due to weak instruments. In the rest of the paper we interpret the Tobit results. We estimate the Tobit models the total sample and for the two subsamples mentioned before (older and younger cohorts) since Wald test of exogeneity are valid for these subsamples.

The Tobit estimates in Table 6 indicate that for days hospitalized, for the total sample the coefficient estimates are negative and statistically significant for both females and males. Further, both for the samples of 1945-1965 (older cohort) and the 1980-1990 (younger cohort) the coefficient estimates are negative and significant for both females and males. For days out of work, for the total sample the coefficient estimates for females are statistically significant and positive for females but negative for males. For the sample of 1945-1965 (older cohort) the coefficient for females are positive and highly significant indicating that for females an increase in years of education also increases the days out of work. However, the coefficient for males are insignificant. For the sample of 1980-1990 (younger cohort) the coefficient for females is again positive and significant indicating that an increase in education increases days out of work but for males negative and significant indicating that an increase in years of education reduces the days out of work.

In the case of a Tobit analysis it is more proper to interpret the marginal effects. In the case of Tobit analysis there are several kinds of marginal effects. The two kinds of marginal effects are reported in Table 7 . They are all computed as average marginal effects. For days hospitalized, in the total sample the marginal effects are all negative for both females and males. In the samples of both 1945-1965 and 1980-1990, all of the marginal effects are negative and significant. This indicated that clearly an increase in years of education reduces the days hospitalized for both females and males. For days out of work, in the total sample, for a female with positive days and for a randomly selected female both of the marginal effects are positive indicating that an increase in education increases the days out of work for females. In the sample of 1945-1965 (older cohort), only the marginal effect on the censored outcome for females is positive and significant. The other marginal effects are insignificant. In the sample of 1980-1990 (younger cohort), both of the marginal effects for females are positive and significant. However for males both of the marginal effects are negative and significant. These outcomes for days out work indicate that clearly an increase in years of education increases the days out of work for females but reduces the days out of work for males. 


\section{Chronic Diseases and Robustness Checks with the Tobit Model}

For further estimation we have repeated the Tobit estimation on joint male and female samples of chronic diseases. We have considered the cases of three diseases. They are Lung Diseases, Heart Diseases and Bone Diseases. These estimations are carried out only for the days hospitalized and the cohorts of two samples of 1945-1965 (the older) and the 1980-1990 (the younger). The Tobit coefficient estimates and the two marginal effects are all negative and significant for the 1945-1965 sample for all of the three diseases indicating that an increase in education reduces the days hospitalized even for the chronically sick. For the 1980-1990 sample negative effects are observed only for the case of lung diseases. However, for this sample the number of observations are substantially reduced hence, not reliable. These results are reported in Table 8.

In order to check the robustness of our results to the inclusion of potentially endogenous variables, we have estimated the Tobit models by including, income, labor market status (this is not known for the 2010 wave of the survey), marital status, health insurance status (for the relevant years) and occupation one by one or simultaneously. When these variables are included one by one the results we have obtained in this paper were robust. However, when occupation was included along with others most of the coefficient estimates lost their significance. However, when all of these variables are included in the case of days out of work in the female samples the positive coefficient estimate of the years of schooling turned negative and was statistically significant in one case. These results are not reported for brevity.

\section{Double Hurdle Model Estimates}

Table 9 presents the Double Hurdle estimates of the participation and intensity equations by gender. For the total sample the effect of years of education on hospitalization decision are negative and statistically significant for both females and males. For the samples of 1945-1965 and 1980-1990 (the older and the younger cohorts respectively) the effect of years of education on hospitalization decision are negative and statistically significant for females but not statistically significant for males. For the total sample, the effect of years of education on out of work decision is positive for females and negative for males which are statistically significant at one and five percent levels respectively. However, for the samples of 1945-1965 and 1980-1990 (the older and the younger cohorts respectively) the effect of years of education on out of work decision is positive and statistically significant at one percent for females but insignificant for males. These results imply that the years of education influences the out of work decision positively for females in the total, older and younger samples while for males the effect is negative in the total sample but insignificant in the older and younger samples.

The three kinds of marginal effects from the Double Hurdle estimates in Table 9 are prepared and reported in Table 10. They are all computed as average marginal effects. We first examine the effect of years of education on days hospitalized. For 
the total sample, all of the marginal effects for both females and males are negative and statistically significant. For the 1945-1965 sample (older cohort) all of the marginal effects are negative and statistically significant except in the male sample for the unconditional marginal effect which is insignificant. For the 1980-1990 sample (younger cohort) all of the marginal effects are negative and statistically significant except in the male sample for the conditional marginal effect which is insignificant. From this discussion we can conclude that an increase in years of education reduces the days hospitalized for both females and males.

Next we examine the effect of years of education on days out of work. For the total sample all of the marginal effects are negative and statistically significant except for females for the unconditional marginal effect which is positive and statistically significant for a randomly selected female. The results are mixed for the older and younger cohorts. In the samples of 1945-1965 (older cohort) the marginal effects are insignificant except for females at the unconditional marginal effect (for a randomly selected female) where it is positive and statistically significant. In the sample of 1980-1990 (younger cohort) conditional marginal effect (for observations which are positive days) is negative and significant for females and insignificant for males while unconditional marginal effect (for a randomly selected individual) is positive for females and negative for males. These indicate that for males clearly an increase in years of education reduces the days out of work in the total sample but loses their significance in some of the older and younger samples. These outcomes for days out work indicate that clearly an increase in years of education increases the days out of work for a randomly selected females but reduces the days out of work for males.

Table 10 also reports the marginal effects on the probability of any hospitalization and any days out of work. In the male and female samples, the marginal effects of education on any hospitalization are statistically significant and negative except in the male sample for the older cohort. These results imply that the education reduces the probability of any days hospitalized. On the other hand, in the male sample the marginal effects of education on any days out of work are statistically significant and negative only in the total sample but not in the older and younger samples. However, in the female sample the marginal effects of education any days out of work are statistically significant and positive. These results imply that the education increases the probability of any days out of work for the females but, the reverse is true for the total males.

\section{7) Conclusions}

This paper investigates the effect of education on days hospitalized and days out of work using the Tobit and Double Hurdle estimates with pooled samples of 2008, 2010, 2012 and 2014 waves of the THS. We find that our instrumental variables estimates are unreliable due to the possibility of weak instruments. Therefore, we estimate Tobit models and Double Hurdle models. The econometric methodology employed considers the fact that the dependent variables, the days hospitalized and 
days out of work contain substantial number of zero observations (days). Such an approach has not been used before to analyze hospitalization days and days out of work in the Turkish case and provides interesting insights. To the best of our knowledge, Arendt (2008) investigated the education effects on days of hospitalization in Denmark however, the education effects on days out of work for health reasons has not been considered in the literature before.

Using the Tobit analysis the main conclusions are as follows. An increase in years of education reduces the days hospitalized unambiguously for both females and males in the total, older and younger cohorts as well. The results for days out of work indicate that an increase in years of education increases the days out of work for females but reduces the days out of work for males in the total, younger and older cohorts. Considering the Double Hurdle models we reach the following conclusions. An increase in years of education reduces the days hospitalized for both males and females supporting the Tobit estimation results. The results for days out of work indicate that for a randomly selected female (unconditional marginal effect) the effect of an increase in years of education is to increase the days out of work. This results also supports the Tobit analysis. The effect of an increase in years of education is to reduce days out of work for males in the total sample but this results mostly lose their significance in the older and younger male samples.

The reduced days of hospitalization due to increased years of education may be due to two effects. One is the lower probability of any hospitalization. The other is the earlier discharges or both. We have not investigated these effects in this study.

Our finding of significant difference between females and males in the education effect on days out of work is also encountered in the literature. Leigh (1983), Paringer (1983), Vistnes (1997), Mastekaasa (2000), Ichino and Moretti (2009) and AlbaRamirez and Lopez-Mourels (2017) have found that women tend to be more out of work than men. While Leigh, Vistnes and Alba-Ramirez and Lopez-Mourels found that this can be attributed to the presence of children other authors such as Paringer (1983) and Vanden Heuvel and Wooden(1995) found that absenteizm is less likely among women with dependents. We did not pursue this avenue and deferred it for future research.

We have no way of checking where do most of the females work. We do not know if they work in public or private sector. In any case, it seems that the better educated females make use of more days out of work than less educated. It is possible that most of the better educated females are working in the public sector and better aware of the possibilities of call for sick days and make liberal use of them.

Our results point to the importance of education one more time. Education effects on health requires considerable more attention from policy makers than it has so far received. This is not necessarily by providing health related information but by investing in the wider impact of education throughout life. The results are relevant not 
only because days lost from work are costly but also because of large health care costs. The findings have implications for the design of policy.

\section{References}

Adams, S. J. (2002). "Educational Attainment and Health: Evidence from a Sample of Older Adults." Education Economics, 10(1): 97-109.

Alba-Ramirez, A. and E. Lopez-Mourelo (2017). " Sickness Absence from Work in Spain : Are There Gender Differences." Madrid, Spain: Department of Economics, Universidad Carlos III De Madrid Working Paper No: 17-15.

Arendt, J. N. (2005). "Does Education Cause Health? A Panel Data Analysis Using School Reforms for Identification." The Economics of Education Review, 24(2): 149-160.

Arendt, J. N. (2008). "In Sickness and in Health- Till Education Do Us Part: Education Effects on Hospitalization." Economics of Education Review, 27: 161-172.

Aristei D. and L. Pieroni (2008). "A Double-Hurdle Approach to Modeling Tobacco Consumption in Italy." Applied Economics 40(19): 2463-2476.

Becker, G.S. (1964). Human Capital. New York, NY: Columbia University Press.

Behrman, J. and Wolfe, B. L. (1989). "Does More Education Make Women Better Nourished and Healthier? Adult Sibling Random and Fixed Effects Estimates for Nicaragua." Journal of Human Resources, 24(1) : 644-663.

Berger, M. and J. P. Leigh, (1989). "Schooling, Self-Selection, and Health." The Journal of Human Resources, 24(3), :431-455.

Berger, M. C. and J. P. Leigh. 1989. "Education, Self-Selection and Health." Journal of Human Resources, 24 (3), 433-455.

Bils, Mark and Peter J. Klenow. (2000) "Does Schooling Cause Growth." American Economic Review, 90(5): 1160-1183.

Bound, J. (1991). "Self-reported Versus Objective Measures of Health in Retirement Models." Journal of Human Resources, 26(1): 106-138.

Burke, W. J. (2009) "Fitting and Interpreting Cragg's Tobit Alternative Using Stata." The Stata Journal 9( 4): 584-592. 
Butler, S. Richard V. Burkhauser, Jean M. Mitchell, and Theodore P. Pincus, (1987). "Measurement Error in Self-Reported Health Variables." The Review of Economics and Statistics, Vol. 69(4): 644-650.

Cameron, A. C., P. K. Trivedi, F. Milne and J. Piggott. (1988). "A Microeconometric Model of the Demand for Health Care and Health Insurance in Australia." Review of Economic Studies, 55: 85-106.

Case, A., A. Fertig and C. Paxson. (2003)."From Cradle to Grave. The Lasting Impact of Childhood Health and Circumstances." Princeton, NJ: Center for Health and Well-being, Woodrow Wilson School of Public and International Affairs, Princeton University Working Paper.

Cong, R. (2000) sg144: "Marginal Effects of the Tobit Model." Stata Technical Bulletin, 56: $27-34$.

Conti, G., J. Heckman and S Urzua (2010). "Education-Health Gradient." American Economic Review, Papers and Proceedings, 100: 234-238.

Cowell, A. (2006). "The Relationship Between Education and Health Behavior: Some Empirical Evidence." Health Economics, 15: 125-146.

Crowley F., J. Eakins and D. Jordan (2012). "Participation, Expenditure and Regressivity in the Irish Lottery: Evidence from Irish Household Budget Survey 2004/2005." The Economic and Social Review, 43(2): 199-225.

Crystal, S, A., T. L. Sasso and U. Sambamoorthi. (1999). "Incidence and Duration of Hospitalizations Among Persons with AIDS: An Event History Approach." Health Services Research, 33 (6): 1611-1638.

Cutler, D., \& Lleras-Muney, A. (2006). "Education and Health: Evaluating Theories and Evidence." Cambridge, MA: National Bureau of Economic Research (NBER) Working Paper No. 12352.

Deaton, Angus, (2003) "Health Inequality and Economic Development." Journal of Economic Literature, XLI (1).

Deaton, Angus. (2003). "Health, Inequality, and Economic Development." Journal of Economic Literature, 41(1): 113-158.

Farrell, Phillip, and Victor R. Fuchs. (1982). "Schooling and Health: The Cigarette Connection." Journal of Health Economics, 1(3): 217-230.

Fuchs, V. R. (1982). Time Preferences and Health: An Exploratory Study. In V. Fuchs (Ed.), Economic aspects of Health, Second NBER Conference on Health in Stanford (pp. 93-119). Chicago: University of Chicago Press. 
Fuchs. V. R. (1982). "Time Preference and Health: An Exploratory Study." In Economic Aspects of Health,. V. R. Fuchs (Ed.), (pp. 93-120) : Chicago, IL: University of Chicago Press.

Gazioglu, S. and A. Tansel (2006) "Job Satisfaction in Britain: Individual and Job Related Factors.” Applied Economics, 38: 1163-1171.

Geil, P. A. Million, R. Rotte, and K. F. Zimmerman (1997). "Economic Incentives and Hospitalization in Germany." Journal of Applied Econometrics, 12: 295-311.

Gilleskie, D., and Harrison, A. (1998). "The Effect of Endogenous Health Inputs on the Relationship Between Health and Education." Economics of Education Review, 17: 279-295.

Grossman, M. (1972). "On the Concept of Health Capital and the Demand for Health." Journal of Political Economy, 80: 223-255.

Grossman, M. (1975). “The Correlation Between Health and Education.” In N. Terleckyj (Ed.), Household Production and Consumption (pp. 147-211). New York, NY: Columbia University Press.

Grossman, M. (2003). "Education and Personal Behaviour.” In E. Hanushek, \& F. Welch (Eds.), Handbook of the Economics of Education. Amsterdam: North-Holland, Elsevier Science.

Grossman, M. and R. Kaestner (1997). "Effects of Education on Health." In J. Behrman, \& N. Stancey (Eds.), The Social Benefits of Education (pp. 69-124). Ann Arbor, MI: The University of Michigan Press.

Hahn, J. and J. Hausman (2002). "A New Specification Test for the Validity of Instrumental Variables." Econometrica, 70: 163-189.

Hartog, J. \& Oosterbeek, H. (1998). "Health, Wealth and Happiness: Why Pursue a Higher Education?" Economics of Education Review, 17: 245-256.

Humphreys B. R., Lee Y. S. and B. P. Soebbing (2010). "Consumer Behaviour in Lottery: the Double Hurdle Approach and Zeros in Gambling Survey Data." International Gambling Studies, 10(2): 165-176.

Ichino, A. and E. Moretti (2009). "Biological Gender Differences, Absenteeism and the Earnings Gap.” American Economic Journal: Applied Economics, 1(1): 183-218.

Jones A. (1989). "A Double-Hurdle Model of Cigarette Consumption." Journal of Applied Econometrics 4(1): 23-39. 
Kane, T. J. and C. E. Rouse (1993). "Labor Market Returns to Two and Four year Colleges: Is a Credit a Credit and Do Degrees Matter?" Cambridge, Massachusetts: National Bureau of Economic Research (NBER) Working Paper No. 7235 .

Kenkel, D. (1991). "Health Behavior, Health Knowledge, and Education." Journal of Political Economy, 99(2): 287-305.

Kenkel, D. (1995). "Should You Eat Breakfast? Estimates from Health Production Functions." Health Economics, 4: 15-29.

Kerkhofs, M., \& Lindeboom, M. (1995). "Subjective Health Measures and StateDependent Reporting Errors." Health Economics, 4: 221-235.

Kırdar, M.G., M. Dayığlu-Tayfur, and İ. Koç (2012) "The Effect of Compulsory Schooling Laws on Teenage Marriage and Births in Turkey." Munich, Germany: MPRA Working Paper No. 38735.

Kreider, Brent, (1999). "Latent Work Disability and Reporting Bias." Journal of Human Resources. 34(4): 734-69.

Lancaster, T. and O. Intrator. (1998). "Panel Data with Survival: Hospitalization of HIVPositive Patients." Journal of the American Statistical Association, 93 (441): 4653.

Leigh, J. (1998). "Parents' Schooling and the Correlation between Education and Frailty." Economics of Education Review, 17: 349-358.

Leigh, J. P. (1983). "Sex Differences in Absenteeism.” Industrial Relations, 22 (3): 349361.

Lindeboom M, and M. Kerkhofs (2002). "Subjective Health Measures, Reporting Errors and the Endogenous Relationship between Health and Work." Bonn, Germany: Institute for the Study of Labor (IZA) Discussion Paper No: 457.

Lleras-Muney, A. (2005). "The Relationship Between Education and Adult Mortality in the US," The Review of Economic Studies, 72(1): 189-221.

Lundborg, P., A. Nilsson and D. O. Rooth (2016). "The Health- Schooling Relationship: Evidence from Swedish Twins." Journal of Population Economics, 29: 11911215.

Mastekaasa, A. (2000). "Parenthood, Gender and Sickness Absence." Social Science and Medicine, 50: 1827-1842. 
McDonald, J. F. and R. A. Moffitt (1980). "The Use of Tobit Analysis." Review of Economics and Statistics, 62: 318-321.

Mwabu, G. (2003). "Health Economics for Low-Income Countries." New Haven, CT: Yale University, Economic Growth Center, Discussion Paper No. 955.

Nawata, K. (1993). "A Note on the Estimation of Models with Sample-Selection Biases." Economic Letters, 42: 15-24.

Palmore, E. and C. Luikart (1972). "Health and Social Factors Related to Life Satisfaction." Journal of Health and Social Behavior, 13(1): 68-80.

Paringer, L. (1983). "Women and Absenteeism: Health or Economics?" American Economic Review, 73(2): 123-127.

Picone, G., F. Slone, S.-Y. Chou and D. Taylor (2003). "Does Higher Hospital Cost Imply Higher Quality of Care?" The Review of Economics and Statistics, 85(1): $51-62$.

Pohlmeier, W. and V. Ulrich. (1995). "An Econometric Model of the Two-Part Decision making Process in the Demand for health Care." The Journal of Humans Resources, 30 (2): 339-361.

Preston, S., and P. Taubman (1994). "Socio-Economic Differences in Adult Mortality and Health Status." In L. Martin, \& S. Preston (Eds.), Demography and Aging (pp. 279-318). Washington, DC: National Academy Press.

Psacharopoulos, G. and H. A. Patrinos (2004). "Returns to Investment in Education: A Further Update." Education Economics, 12(2): 111-134.

Pudney S. (1989) Modelling Individual Choice: The Econometrics of Corners, Kinks and Holes. Massachusetts, USA: Blackwell Publishing.

Riphahn, R., A. Wambach and A. Million. (2003). "Incentive Effects in the Demand for Health Care: A Bivariate Panel Count Data Estimation." Journal of Applied Econometrics, 18: 387-405.

Rivers, D. and Q. H. Vuong (1988). "Limited Information Estimators and Exogeneity Tests for Simultaneous Probit Models." Journal of Econometrics, 39: 347-366.

Rosenzweig, M. R. And T. P. Schultz (1983). "Estimating a Household Production Function: Heterogeneity, the Demand for Health Inputs, and Their Effects on Birth Weight." The Journal of Political Economy, 91(5): 723-746. 
Schultz, T. P. (2004). "Education, Investment and Returns." in H. Chenery and T: N. Srinivasan (Eds.)". Handbook of Development Economics, 1: 543-630. Amsterdam, Netherlands: North-Holland.

Schultz, T. Paul (1997) "Assessing the Productive Benefits of Nutrition and Health: An Integrated Human Capital Approach." Journal of Econometrics, 77: 141-158.

Schultz, T. Paul (2005) "Productive Benefits of Health: Evidence from Low Income Countries." in Lopez Casasnovas G., Berta Riveras and L. Currais (eds.) Health and Economic Growth Findings and Policy Implications, Cambridge, MA: MIT Press.

Schultz, T. P. and A. Tansel (1997) "Wage and Labor Supply Effects of Illness in Côte d'lvoire and Ghana: Instrumental Variable Estimates for Days Disabled." Journal of Development Economics, 53: 251-286.

Silles, M. A. (2009). "The Causal Effect of Education on Health: Evidence from the United Kingdom." Economics of Educaiton Review, 28: 122-128.

Spasojevic, J. (2003). Effects of Education on Adult Health in Sweden: Results from a Natural Experiment. Ph.D.-Thesis, Graduate School for Public Affairs and Administration, New Yok, NY: Metropolitan College of New York.

Stock, J. H. and M. Yogo (2005) "Asymptotic Distribution of Instrumental variables Statistics with many Instruments." In Identification and Inference for Econometric Models: Essays in Honor of Thomas Rothenberg, D.W.K. Andrews and J. H. Stock (editors).:109-120. Cambridge: Cambridge University Press.

Tansel, A. (2002). "Turkey." in World Health Systems Bruce J. Fried and Laura M. Gaydos (Eds.), Chicago, Illinois: Health Administration Press.

Tansel, A. (2012). "Health System of Turkey." in World Health Systems, Challenges and Perspectives, Second Edition B.J. Fried and L. M. Gaydos (Eds.) Chicago, Illinois: Health Administration Press. (381-407).

Tansel, A. and D. Karaoglan (2014). "Health Behaviors and Education in Turkey." Bonn, Germany: Institute for the Study of Labor (IZA) Discussion Paper No.8262.

Tansel, A. and D. Karaoglan (2016). "The Causal Effect of Education on Health Behaviors: Evidence from Turkey." Bonn, Germany: Institute for the Study of Labor (IZA) Discussion Paper No. 10020.

Thomas, D. and J. Strauss (1997). "Health and Wages: Evidence on Men and Women in Urban Brazil." Journal of Econometrics, 77(1): 159-185.

Tobin J. (1958). "Estimation of Relationships for Limited Dependent Variables." 
Econometrica, 26(1): 24-36.

Vanden Heuvel, A. and M. Wooden (1995). "Do Explanations of Absenteeism Differ for Men and Women." Human Relations, 48(11): 1309-1329.

Vistnes, J. P. (1997). "Gender Differences in Days Lost from Work Due to Illness." Industrial and Labor Relations Review, 50(2): 304-323.

Weil, D. (2007). "Accounting for the Effect of Health on Economic Growth." Quarterly Journal of Economics, 122 (3): 1265-1306. 
Figure 1: Histogram of Days Hospitalized by Gender

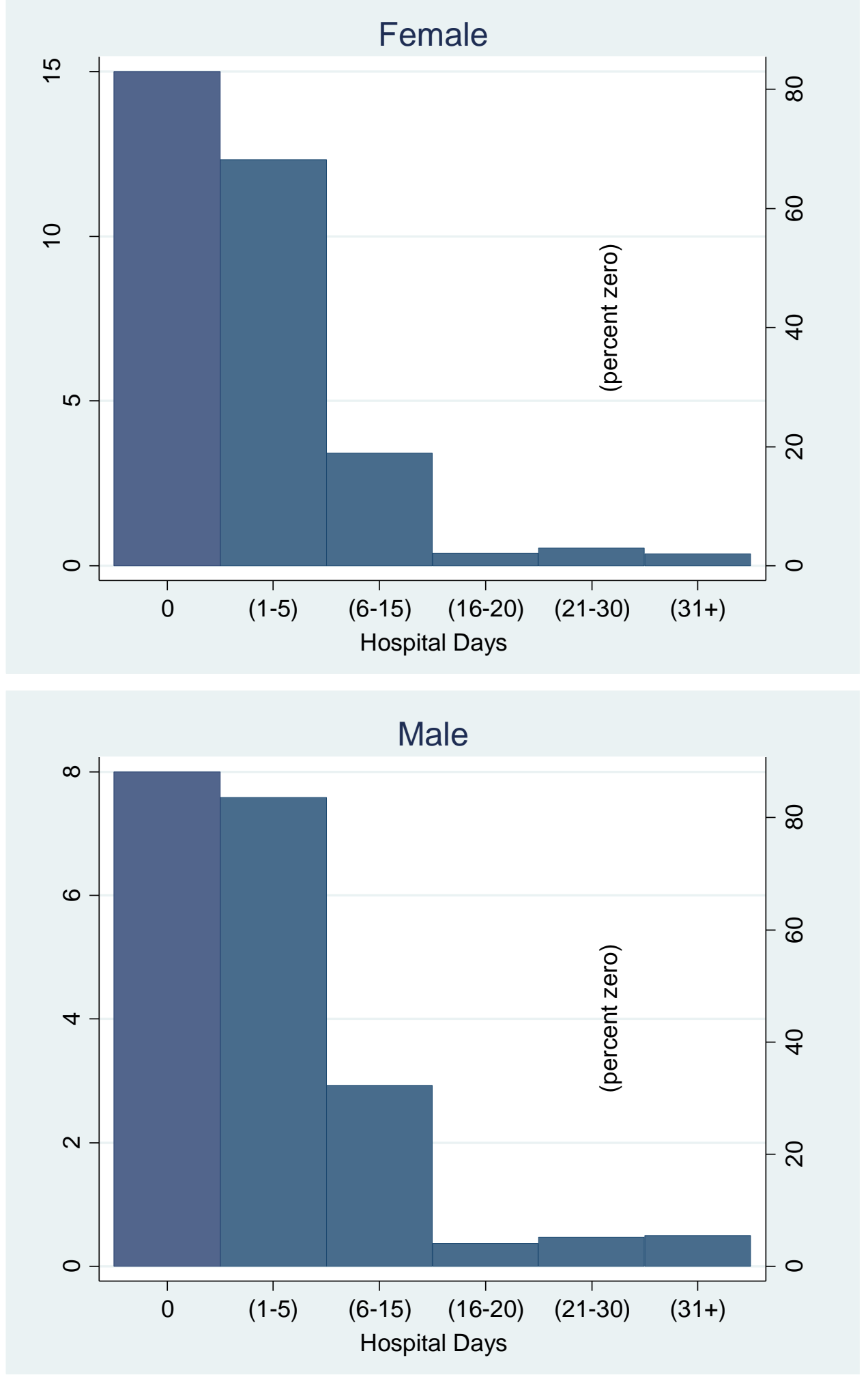

Source: Authors computations using THS 2008, 2010, 2012 and 2014. 
Figure 2: Histogram of Days out of Work for Wage-Earners by Gender
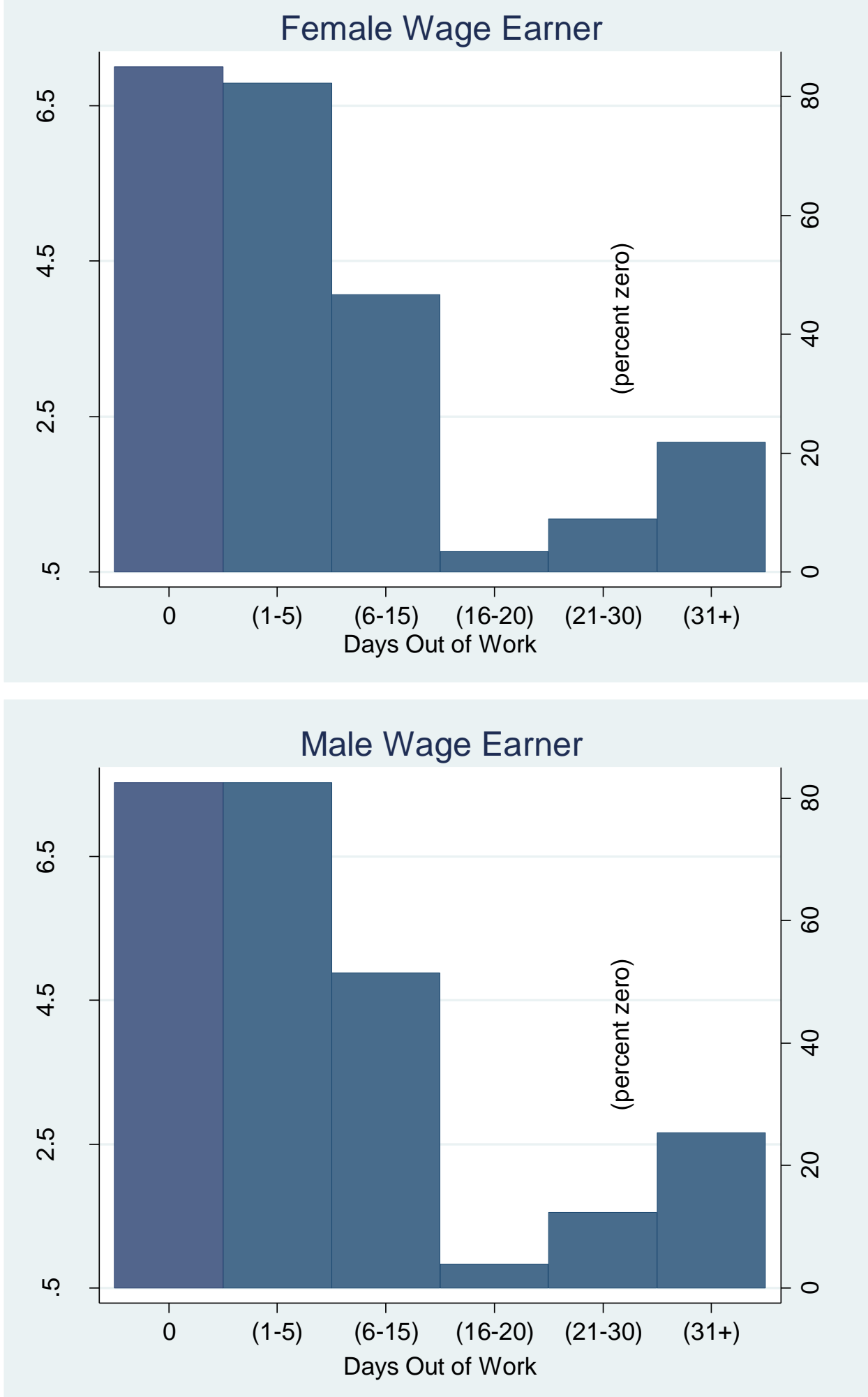

Source: Authors computations using THS 2008, 2010, 2012 and 2014. 
Figure 3: Histogram of Days out of Work for Self-Employed by Gender
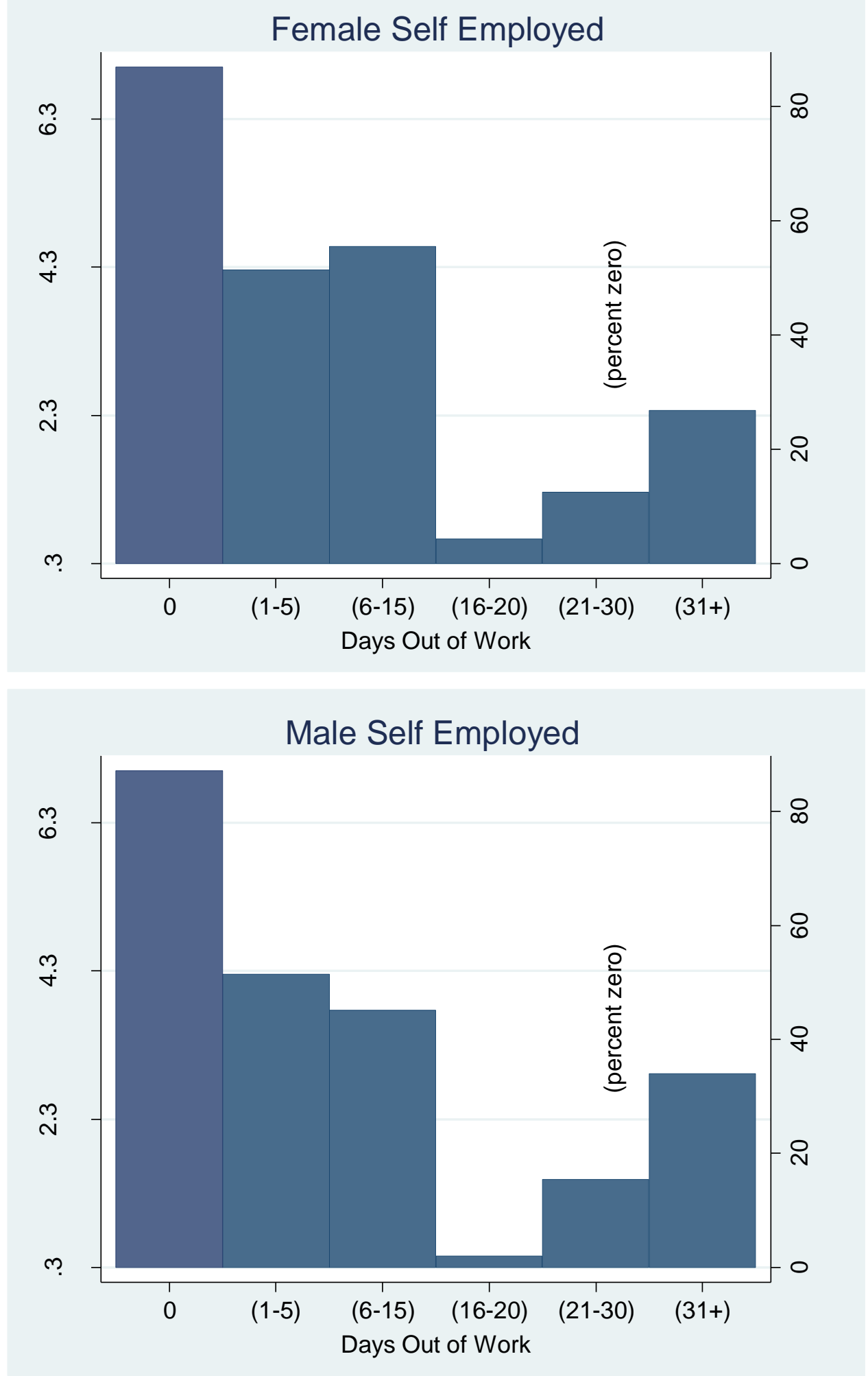

Source: Authors computations using THS 2008, 2010, 2012 and 2014. 
Figure 4: The Effects of 1961 Educational Reform and 1987 Educational Reform on Alternative Schooling Outcomes by Birth Cohorts
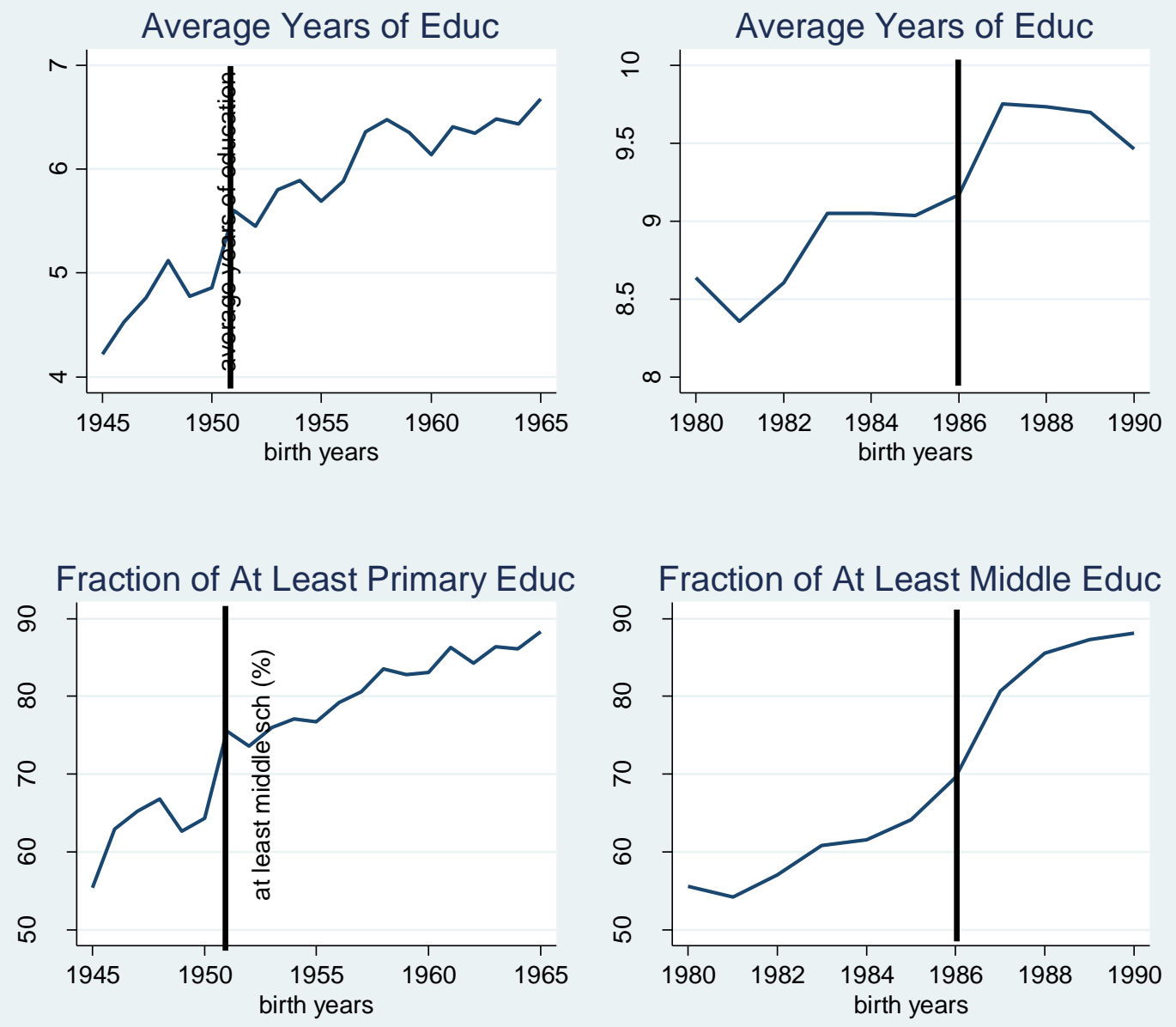

Fraction of 5 Years Educ
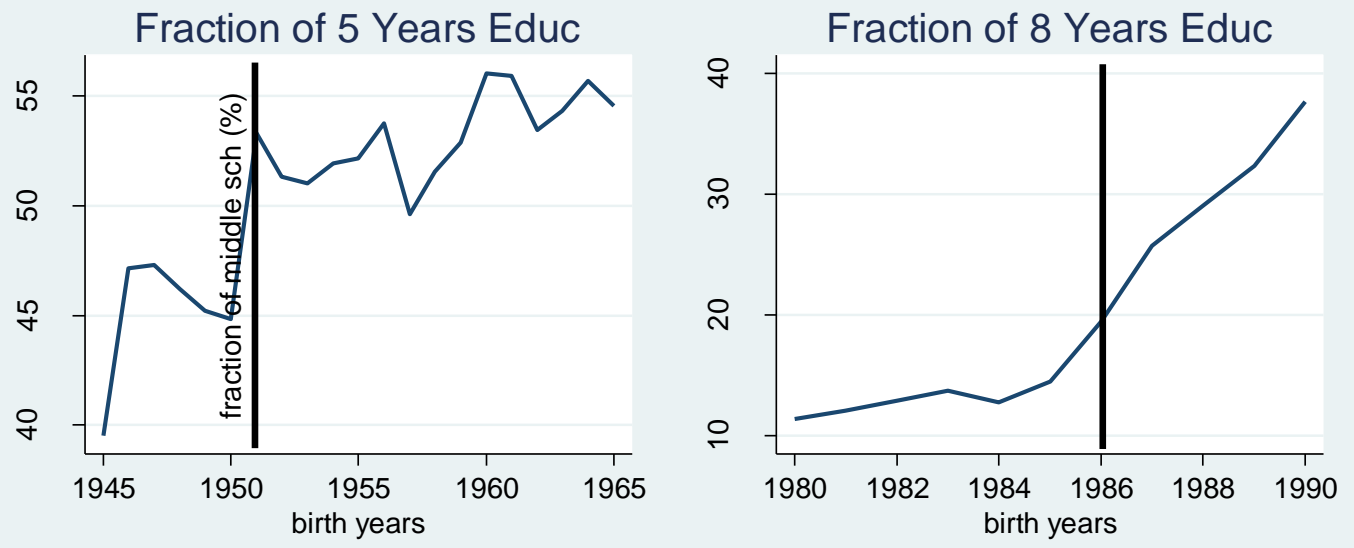

Source: Authors computations using THS 2008, 2010, 2012 and 2014. 
Table 1: Means and Standard Deviation of Observations with Zero and Positive Days of Hospitalization, 2008-2014, Turkey

\begin{tabular}{|c|c|c|c|c|c|}
\hline \multirow[b]{2}{*}{ Female } & \multicolumn{2}{|c|}{ Zero Days } & \multicolumn{2}{|c|}{ Positive Days } & \multirow[b]{2}{*}{$\begin{array}{c}\text { mean-comparison } \\
\text { test (p-value) }\end{array}$} \\
\hline & Mean & $\begin{array}{l}\text { Standard } \\
\text { Deviation }\end{array}$ & Mean & $\begin{array}{l}\text { Standard } \\
\text { Deviation }\end{array}$ & \\
\hline Days Hospitalized & 0 & 0 & 5.844 & 10.512 & $0.000 * * *$ \\
\hline Middle (at least) & 0.419 & 0.493 & 0.349 & 0.477 & $0.000 * * *$ \\
\hline Primary (at least) & 0.799 & 0.401 & 0.733 & 0.443 & $0.000 * * *$ \\
\hline Age & 38.311 & 14.495 & 40.655 & 14.732 & $0.000 * * *$ \\
\hline Age Square & 1677.838 & 1176.086 & 1869.779 & 1274.046 & $0.000 * * *$ \\
\hline Years of Education & 6.555 & 4.313 & 6.017 & 4.49 & $0.000 * * *$ \\
\hline Primary and Less & 0.581 & 0.493 & 0.651 & 0.477 & $0.000 * * *$ \\
\hline Middle & 0.167 & 0.373 & 0.129 & 0.336 & $0.000 * * *$ \\
\hline High & 0.159 & 0.366 & 0.128 & 0.334 & $0.000 * * *$ \\
\hline Univ. and Above & 0.094 & 0.291 & 0.092 & 0.289 & 0.7497 \\
\hline \multirow[t]{3}{*}{ Num. of Observation } & \multicolumn{2}{|l|}{19251} & \multicolumn{2}{|l|}{3946} & \\
\hline & \multicolumn{2}{|c|}{ Zero Days } & \multicolumn{2}{|c|}{ Positive Days } & \\
\hline & Mean & $\begin{array}{l}\text { Standard } \\
\text { Deviation }\end{array}$ & Mean & $\begin{array}{l}\text { Standard } \\
\text { Deviation }\end{array}$ & $\begin{array}{c}\text { mean-comparison } \\
\text { test ( } \mathrm{p} \text {-value) }\end{array}$ \\
\hline Days Hospitalized & 0 & 0 & 8.236 & 16.127 & $0.000 * * *$ \\
\hline Middle (at least) & 0.584 & 0.493 & 0.48 & 0.5 & $0.000 * * *$ \\
\hline Primary (at least) & 0.942 & 0.234 & 0.915 & 0.279 & $0.000 * * *$ \\
\hline Age & 38.386 & 14.485 & 44.623 & 15.549 & $0.000 * * *$ \\
\hline Age Square & 1683.314 & 1167.33 & 2232.881 & 1349.967 & $0.000 * * *$ \\
\hline Years of Education & 8.241 & 3.934 & 7.599 & 3.958 & $0.000 * * *$ \\
\hline Primary and Less & 0.416 & 0.493 & 0.52 & 0.5 & $0.000 * * *$ \\
\hline Middle & 0.22 & 0.414 & 0.178 & 0.382 & $0.000 * * *$ \\
\hline High & 0.22 & 0.414 & 0.182 & 0.386 & $0.000 * * *$ \\
\hline Univ. and Above & 0.144 & 0.351 & 0.12 & 0.325 & $0.001 * * *$ \\
\hline
\end{tabular}

Num. of Observation 16944

2276

Source: Turkish Health Survey 2008-2010-2012-2014.

Note: This table is based on a sample of individuals 18-69 years of age. ***, **and * indicate significance at 1, 5 and 10 percent levels. 
Table 2: Means and Standard Deviation of Observations with Zero and Positive Days Out of Work, 2008-2014, Turkey

\begin{tabular}{|c|c|c|c|c|c|}
\hline \multirow[b]{3}{*}{ Female } & \multicolumn{2}{|c|}{ Zero Days } & \multicolumn{2}{|c|}{ Positive Days } & \multirow{3}{*}{$\begin{array}{c}\text { mean-comparison } \\
\text { test (p-value) }\end{array}$} \\
\hline & & Standard & & Standard & \\
\hline & Mean & Deviation & Mean & Deviation & \\
\hline Days Out of Work & 0 & 0 & 14.613 & 19.614 & $0.000 * * *$ \\
\hline Middle (at least) & 0.395 & 0.489 & 0.62 & 0.485 & $0.000 * * *$ \\
\hline Primary (at least) & 0.783 & 0.412 & 0.914 & 0.281 & $0.000 * * *$ \\
\hline Age & 38.498 & 14.69 & 35.909 & 10.616 & $0.000 * * *$ \\
\hline Age Square & 1697.906 & 1198.648 & 1402.085 & 834.309 & $0.000 * * *$ \\
\hline Years of Education & 6.267 & 4.211 & 9.52 & 4.927 & $0.000 * * *$ \\
\hline Primary and Less & 0.605 & 0.489 & 0.38 & 0.485 & $0.000 * * *$ \\
\hline Middle & 0.167 & 0.373 & 0.111 & 0.314 & $0.000 * * *$ \\
\hline High & 0.151 & 0.358 & 0.175 & 0.38 & $0.000 * * *$ \\
\hline Univ. and Above & 0.077 & 0.267 & 0.334 & 0.472 & $0.001 * * *$ \\
\hline \multirow[t]{3}{*}{ Num. of Observation } & \multicolumn{2}{|l|}{19819} & \multicolumn{2}{|l|}{1125} & \\
\hline & \multicolumn{2}{|c|}{ Zero Days } & \multicolumn{2}{|c|}{ Positive Days } & \\
\hline & Mean & $\begin{array}{l}\text { Standard } \\
\text { Deviation }\end{array}$ & Mean & $\begin{array}{l}\text { Standard } \\
\text { Deviation }\end{array}$ & $\begin{array}{c}\text { mean-comparison } \\
\text { test (p-value) }\end{array}$ \\
\hline Days Out of Work & 0 & 0 & 20.693 & 32.631 & $0.000 * * *$ \\
\hline Middle (at least) & 0.579 & 0.494 & 0.574 & 0.495 & 0.659 \\
\hline Primary (at least) & 0.935 & 0.246 & 0.964 & 0.186 & $0.000 * * *$ \\
\hline Age & 38.306 & 15.011 & 37.476 & 10.69 & $0.000 * * *$ \\
\hline Age Square & 1692.654 & 1208.56 & 1518.687 & 853.536 & $0.000 * * *$ \\
\hline Years of Education & 8.136 & 3.92 & 8.532 & 3.986 & $0.000 * * *$ \\
\hline Primary and Less & 0.421 & 0.494 & 0.426 & 0.495 & 0.659 \\
\hline Middle & 0.226 & 0.419 & 0.182 & 0.386 & $0.000 * * *$ \\
\hline High & 0.217 & 0.412 & 0.225 & 0.417 & $0.039 * *$ \\
\hline Univ. and Above & 0.135 & 0.342 & 0.168 & 0.374 & $0.000 * * *$ \\
\hline Num. of Observation & 14861 & & 2721 & & \\
\hline
\end{tabular}

Source: Turkish Health Survey 2008-2010-2012-2014.

Note: This table is based on a sample of individuals 18-69 years of age. ***, **and * indicate significance at 1, 5 and 10 percent levels. 
Table 3: Average Number of Days of Hospitalization in the Last Year by Gender, Age, Education, 2008-2014, Turkey

\begin{tabular}{|c|c|c|c|c|c|}
\hline & ary or Less & Middle & High & Univ. and Above & All Levels of Educ. \\
\hline \multicolumn{6}{|l|}{ All Female } \\
\hline Age $15-39$ & 0.737 & 0.522 & 0.516 & 0.599 & 0.621 \\
\hline (Number of Obs.) & 5322 & 3155 & 2582 & 1526 & 12585 \\
\hline Age40 or above & 1.608 & 1.446 & 0.67 & 0.346 & 1.436 \\
\hline (Number of Obs.) & 8424 & 565 & 984 & 639 & 10612 \\
\hline \multicolumn{6}{|l|}{ All Male } \\
\hline Age $15-39$ & 0.87 & 0.481 & 0.487 & 0.314 & 0.56 \\
\hline (Number of Obs.) & 2644 & 3134 & 2764 & 1495 & 10037 \\
\hline Age40 or above & 1.728 & 1.328 & 0.958 & 0.668 & 1.429 \\
\hline (Number of Obs.) & 5594 & 1000 & 1378 & 1211 & 9183 \\
\hline \multicolumn{6}{|l|}{ Female wage earners } \\
\hline Age $15-39$ & 0.445 & 0.84 & 0.451 & 0.498 & 0.52 \\
\hline (Number of Obs.) & 903 & 511 & 1012 & 1182 & 3608 \\
\hline Age40 or above & 1.26 & 1.065 & 0.823 & 0.252 & 0.924 \\
\hline (Number of Obs.) & 1186 & 185 & 526 & 551 & 2448 \\
\hline \multicolumn{6}{|l|}{ Male wage earners } \\
\hline Age $15-39$ & 0.662 & 0.542 & 0.353 & 0.26 & 0.465 \\
\hline (Number of Obs.) & 1733 & 1344 & 1710 & 1237 & 6024 \\
\hline Age40 or above & 1.372 & 1.261 & 0.754 & 0.643 & 1.129 \\
\hline (Number of Obs.) & 3223 & 694 & 1040 & 1004 & 5961 \\
\hline \multicolumn{6}{|l|}{ Female self-employed } \\
\hline Age 15-39 & 0.404 & 0.161 & 0.17 & 0.795 & 0.389 \\
\hline (Number of Obs.) & 104 & 31 & 47 & 39 & 221 \\
\hline Age 40 or above & 1.55 & 4.692 & 0.291 & 0 & 1.476 \\
\hline (Number of Obs.) & 369 & 26 & 55 & 31 & 481 \\
\hline \multicolumn{6}{|l|}{ Male self- employed } \\
\hline Age $15-39$ & 0.571 & 0.167 & 0.295 & 0.242 & 0.376 \\
\hline (Number of Obs.) & 487 & 258 & 292 & 128 & 1165 \\
\hline Age 40 or above & 1.611 & 0.97 & 0.884 & 0.367 & 1.391 \\
\hline (Number of Obs.) & 1987 & 269 & 285 & 177 & 2718 \\
\hline
\end{tabular}

Source: Turkish Health Survey 2008-2010-2012-2014.

Notes: The 2010 survey is not included because it does not include wage earners / self-employed division. 
Table 4: Average Number of Days Out of Work in the Last Year by Gender, Age, Education, 2008-2014, Turkey

\begin{tabular}{|c|c|c|c|c|c|}
\hline & Primary or Less & Middle & High & Univ. and Above & All Levels of Educ \\
\hline \multicolumn{6}{|l|}{ All Female } \\
\hline Age 15-39 & 0.649 & 0.509 & 0.721 & 2.662 & 0.864 \\
\hline (Number of Obs.) & 4,898 & 2,934 & 2,339 & 1,354 & 11,525 \\
\hline Age40 or above & 0.568 & 0.67 & 1.064 & 1.749 & 0.688 \\
\hline (Number of Obs.) & 7,518 & 494 & 853 & 554 & 9,419 \\
\hline \multicolumn{6}{|l|}{ All Male } \\
\hline Age $15-39$ & 4.142 & 2.248 & 2.601 & 2.458 & 2.879 \\
\hline (Number of Obs.) & 2,563 & 2,996 & 2,649 & 1,445 & 9,653 \\
\hline Age 40 or above & 3.759 & 4.574 & 3.248 & 2.399 & 3.596 \\
\hline (Number of Obs.) & 4,852 & 864 & 1,189 & 1,024 & 7,929 \\
\hline \multicolumn{6}{|l|}{ Female Wage Earner } \\
\hline Age $15-39$ & 2.009 & 2.459 & 1.643 & 2.785 & 2.225 \\
\hline (Number of Obs.) & 800 & 447 & 880 & 1,037 & 3,164 \\
\hline Age 40 or above & 1.575 & 0.843 & 1.711 & 1.512 & 1.539 \\
\hline (Number of Obs.) & 1,007 & 140 & 432 & 473 & 2,052 \\
\hline \multicolumn{6}{|l|}{ Male Wage Earner } \\
\hline Age 15-39 & 3.947 & 3.636 & 3.465 & 2.432 & 3.427 \\
\hline (Number of Obs.) & 1,638 & 1,269 & 1,605 & 1,185 & 5,697 \\
\hline Age 40 or above & 3.34 & 3.386 & 2.811 & 2.069 & 3.04 \\
\hline (Number of Obs.) & 2,758 & 586 & 901 & 846 & 5,091 \\
\hline \multicolumn{6}{|l|}{ Female self employed } \\
\hline Age $15-39$ & 2.22 & 3.929 & 0.738 & 5.114 & 2.644 \\
\hline (Number of Obs.) & 100 & 28 & 42 & 35 & 205 \\
\hline Age 40 or above & 1.759 & 4.125 & 2.444 & 1.103 & 1.922 \\
\hline (Number of Obs.) & 323 & 24 & 45 & 29 & 421 \\
\hline \multicolumn{6}{|l|}{ Male self employed } \\
\hline Age $15-39$ & 4.303 & 2.833 & 1.496 & 2.121 & 3.053 \\
\hline (Number of Obs.) & 468 & 227 & 274 & 116 & 1,085 \\
\hline Age 40 or above & 3.383 & 5.439 & 3.397 & 1.127 & 3.452 \\
\hline (Number of Obs.) & 1,769 & 244 & 242 & 150 & 2,405 \\
\hline
\end{tabular}

Source: Turkish Health Survey 2008-2010-2012-2014.

Notes: The 2010 survey is not included because it does not include wage earners / self-employed division. 
Table 5: First Stage Results by Gender, 2008-2014, Turkey

\begin{tabular}{|c|c|c|}
\hline \multirow[b]{2}{*}{ Sample of Days Hospitalized } & Female & Male \\
\hline & $(\mathrm{OLS})$ & $(\mathrm{OLS})$ \\
\hline \multicolumn{3}{|c|}{ Sample of 1945-1965 Cohort (PD 1961) } \\
\hline \multirow[t]{2}{*}{ Reform 1961} & -0.1951 & $0.7105 * *$ \\
\hline & $(0.2735)$ & $(0.2851)$ \\
\hline T statistics & -0.71 & 2.49 \\
\hline F Statistics & 20.12 & 3.76 \\
\hline Number of Obs. & 5,321 & 4,798 \\
\hline \multicolumn{3}{|c|}{ Sample of 1980-1990 Cohort (PD 1997) } \\
\hline \multirow[t]{2}{*}{ Reform 1997} & $0.8383 * * *$ & $0.7803 * *$ \\
\hline & $(0.3134)$ & $(0.3251)$ \\
\hline T statistics & 2.67 & 2.40 \\
\hline F Statistics & 22.68 & 6.40 \\
\hline \multirow[t]{2}{*}{ Number of Obs. } & 5,150 & 3,778 \\
\hline & Female & Male \\
\hline Sample of Days out of Work & $(\mathrm{OLS})$ & $(\mathrm{OLS})$ \\
\hline \multicolumn{3}{|c|}{ Sample of 1945-1965 Cohort (PD 1961) } \\
\hline \multirow[t]{2}{*}{ Reform 1961} & -0.114 & $0.5309 *$ \\
\hline & $(0.2887)$ & $(0.3113)$ \\
\hline T statistics & $-0,39$ & 1,71 \\
\hline F Statistics & 17.52 & 2.67 \\
\hline Number of Obs. & 4,766 & 4,108 \\
\hline \multicolumn{3}{|c|}{ Sample of 1980-1990 Cohort (PD 1997) } \\
\hline \multirow[t]{2}{*}{ Reform 1997} & $1.0046 * * *$ & $0.8251 * *$ \\
\hline & $(0.3338)$ & $(0.3294)$ \\
\hline T statistics & 3,01 & 2,505 \\
\hline F Statistics & 19.93 & 7.01 \\
\hline Number of Obs. & 4,631 & 3,644 \\
\hline
\end{tabular}

Source: Authors computations using THS 2008, 2010, 2012 and 2014.

Notes: Robust standard errors are in parenthesis. ***, **and * indicate significance at 1, 5 and 10 percent levels. First stage results are OLS regressions of years of schooling on Policy Reform1961 (PD1961) or Policy Reform 1997 (PD1997), age, age squared and a time trend with its square and cube, Dummies for NUTS2 26 Regions of Residence and a Constant. These are not reported for brevity. 
Table 6: Tobit and IV-Tobit Estimation Results by Gender, 2008-2014, Turkey

\begin{tabular}{|c|c|c|c|c|}
\hline \multirow[b]{2}{*}{ Days Hospitalized } & \multicolumn{2}{|c|}{ Female } & \multicolumn{2}{|c|}{ Male } \\
\hline & (tobit) & (iv-tobit) & (tobit) & (iv-tobit) \\
\hline \multicolumn{5}{|l|}{ Total } \\
\hline Years of Education & $\begin{array}{c}-0.258^{* * *} * \\
(0.0529)\end{array}$ & - & $\begin{array}{c}-0.396 * * * \\
(0.0593)\end{array}$ & - \\
\hline Log pseudo likelihood & -20687.79 & - & -13297.04 & - \\
\hline Pseudo R2 & 0.0465 & & 0.0603 & \\
\hline No. of Uncensored Obs. & 3805 & - & 2195 & - \\
\hline Number of Obs. & 22,884 & & 18,848 & \\
\hline \multicolumn{5}{|c|}{ Sample of 1945-1965 Cohort (PD 1961) } \\
\hline Years of Education & $\begin{array}{c}-0.515^{* * * *} \\
(0.127)\end{array}$ & $\begin{array}{l}-2.326 \\
(10.24)\end{array}$ & $\begin{array}{c}-0.386^{* * *} * \\
(0.118)\end{array}$ & $\begin{array}{c}3.438 \\
(4.364)\end{array}$ \\
\hline Wald test of exogeneity & & 0.03 & & 0.88 \\
\hline$P$-Value & & 0.855 & & 0.348 \\
\hline Log pseudo likelihood & -4911.94 & & -4167.22 & \\
\hline Pseudo R2 & 0.049 & & 0.046 & \\
\hline No. of Uncensored Obs. & 851 & 851 & 661 & 661 \\
\hline Number of Obs. & 5,321 & 5,321 & 4,798 & 4,798 \\
\hline \multicolumn{5}{|c|}{ Sample of 1980-1990 Cohort (PD 1997) } \\
\hline Years of Education & $\begin{array}{l}-0.135^{*} \\
(0.0726)\end{array}$ & $\begin{array}{c}1.682 \\
(1.345)\end{array}$ & $\begin{array}{c}-0.242 * * \\
(0.108)\end{array}$ & $\begin{array}{c}5.547 \\
(4.704)\end{array}$ \\
\hline Wald test of exogeneity & & 2.46 & & 2.06 \\
\hline$P$-Value & & 0.1171 & & 0.1514 \\
\hline Log pseudo likelihood & -4860.62 & & -1987.47 & \\
\hline Pseudo R2 & 0.0385 & & 0.0696 & \\
\hline No. of Uncensored Obs. & 988 & 988 & 326 & 326 \\
\hline \multirow[t]{2}{*}{ Number of Obs. } & 5,150 & 5,150 & 3,778 & 3,778 \\
\hline & \multicolumn{2}{|c|}{ Female } & \multicolumn{2}{|c|}{ Male } \\
\hline Days out of Work & (tobit) & (iv-tobit) & (tobit) & (iv-tobit) \\
\hline \multicolumn{5}{|l|}{ Total } \\
\hline Years of Education & $\begin{array}{c}1.846 * * * \\
(0.160)\end{array}$ & - & $\begin{array}{c}-0.651 * * * \\
(0.134)\end{array}$ & - \\
\hline Log pseudo likelihood & -7809.22 & - & -17860.71 & - \\
\hline Pseudo R2 & 0.0872 & & 0.0554 & \\
\hline No. of Uncensored Obs. & 1117 & - & 2706 & - \\
\hline Number of Obs. & 20,936 & & 17,567 & \\
\hline \multicolumn{5}{|c|}{ Sample of 1945-1965 Cohort (PD1961) } \\
\hline Years of Education & $\begin{array}{c}1.854 * * * \\
(0.371)\end{array}$ & $\begin{array}{l}-6.105 \\
(100.0)\end{array}$ & $\begin{array}{l}-0.235 \\
(0.300)\end{array}$ & $\begin{array}{c}21.12 \\
(21.21)\end{array}$ \\
\hline Wald test of exogeneity & & 0.01 & & 1.56 \\
\hline P-Value & & 0.935 & & 0.211 \\
\hline Log pseudo likelihood & -1224.52 & & -3676.99 & \\
\hline Pseudo R2 & 0.063 & & 0.035 & \\
\hline No. of Uncensored Obs. & 157 & 157 & 512 & 512 \\
\hline Number of Obs. & 4,766 & 4766 & 4,108 & 4108 \\
\hline
\end{tabular}




\section{Sample of 1980-1990 Cohort (PD1997)}

Years of Education

$1.911 * * *$

$9.423 *$

$-0.497 * * *$

9.506

Wald test of exogeneity

(0.277)

(5.039)

(0.130)

(7.463)

$P$-Value

2.96

2.52

Log pseudo likelihood

0.085

Pseudo R2

$-2240.90$

0.098

$-4346.32$

349

0.061

No. of Uncensored Obs.

4,631

349

706

706

4,631

3,644

Source: Authors computations using THS 2008, 2010, 2012 and 2014.

Notes: Standard errors are clustered by birth year and are given in the parenthesis under the coefficients. $* * *, * *$ and $*$ indicate significance at 1 , 5and 10 percent levels. Each of the regressions includes a constant, age, age squared and a time trend with its square and cube and dummies for NUTS2 26 regions of residence. These are not reported for brevity. 
Table 7: Marginal Effects from Tobit Estimation Results by Gender, 2008-2014, Turkey

\begin{tabular}{|c|c|c|c|c|}
\hline \multirow[b]{2}{*}{$\begin{array}{l}\text { Days } \\
\text { Hospitalized }\end{array}$} & \multicolumn{2}{|c|}{ Female } & \multicolumn{2}{|c|}{ Male } \\
\hline & $\begin{array}{c}\text { Average marginal } \\
\text { effects } \\
\text { on conditional } \\
\text { outcome }\end{array}$ & $\begin{array}{c}\text { Average marginal } \\
\text { effects } \\
\text { on the } \\
\text { unconditional } \\
\text { outcome } \\
\end{array}$ & $\begin{array}{c}\text { Average marginal } \\
\text { effects } \\
\text { on conditional } \\
\text { outcome }\end{array}$ & $\begin{array}{c}\text { Average marginal } \\
\text { effects } \\
\text { on the } \\
\text { unconditional } \\
\text { outcome } \\
\end{array}$ \\
\hline $\begin{array}{l}\text { Total } \\
\text { Years of } \\
\text { Education }\end{array}$ & $\begin{array}{c}-0.0494 * * * \\
(0.009)\end{array}$ & $\begin{array}{c}-0.0382 * * * \\
(0.0075)\end{array}$ & $\begin{array}{c}-0.0661 * * * \\
(0.0096)\end{array}$ & $\begin{array}{c}-0.0409 * * * \\
(0.0058)\end{array}$ \\
\hline $\begin{array}{l}\text { Sample of } 19 \\
\text { Years of } \\
\text { Education }\end{array}$ & $\begin{array}{c}\text { 5-1965 Cohort } \\
\\
-0.0987 * * * \\
(0.0238)\end{array}$ & $\begin{array}{c}-0.0762 * * * \\
(0.0179)\end{array}$ & $\begin{array}{c}-0.06919 * * * \\
(0.021)\end{array}$ & $\begin{array}{c}-0.0479 * * * \\
(0.0144)\end{array}$ \\
\hline $\begin{array}{l}\text { Sample of } 19 \\
\text { Years of } \\
\text { Education }\end{array}$ & $\begin{array}{l}\text { 0-1990 Cohort } \\
\begin{array}{c}-0.0274 * * \\
(0.0145)\end{array}\end{array}$ & $\begin{array}{c}-0.0229 * * \\
(0.012)\end{array}$ & $\begin{array}{c}-0.0365 * * \\
(0.0161)\end{array}$ & $\begin{array}{c}-0.0187 * * \\
(0.0081)\end{array}$ \\
\hline $\begin{array}{l}\text { Days out of } \\
\text { Work }\end{array}$ & $\begin{array}{c}\text { Fe } \\
\text { Average marginal } \\
\text { effects } \\
\text { on conditional } \\
\text { outcome }\end{array}$ & $\begin{array}{l}\text { Average marginal } \\
\text { effects } \\
\text { on the } \\
\text { unconditional } \\
\text { outcome }\end{array}$ & $\begin{array}{c}\mathrm{M} \\
\text { Average marginal } \\
\text { effects } \\
\text { on conditional } \\
\text { outcome }\end{array}$ & $\begin{array}{l}\text { Average marginal } \\
\text { effects } \\
\text { on the } \\
\text { unconditional } \\
\text { outcome }\end{array}$ \\
\hline $\begin{array}{l}\text { Total } \\
\text { Years of } \\
\text { Education }\end{array}$ & $\begin{array}{c}0.2386 * * * \\
(0.0199)\end{array}$ & $\begin{array}{c}0.0908 * * * \\
(0.0073)\end{array}$ & $\begin{array}{c}-0.1202 * * * \\
(0.0250)\end{array}$ & $\begin{array}{c}-0.0898 * * * \\
(0.0189)\end{array}$ \\
\hline $\begin{array}{l}\text { Sample of } 19 \\
\text { Years of } \\
\text { Education }\end{array}$ & $\begin{array}{r}\mathbf{5}-1965 \text { Cohort } \\
0.2147 \\
(0.1353)\end{array}$ & $\begin{array}{c}0.0584 * * * \\
(0.0107)\end{array}$ & $\begin{array}{l}-0.0412 \\
(0.0529)\end{array}$ & $\begin{array}{l}-0.0276 \\
(0.0356)\end{array}$ \\
\hline $\begin{array}{l}\text { Sample of } 19 \\
\text { Years of } \\
\text { Education }\end{array}$ & $\begin{array}{c}0.2697 * * * \\
(0.0427)\end{array}$ & $\begin{array}{c}0.1298 * * * \\
(0.0189)\end{array}$ & $\begin{array}{c}-0.0996 * * * \\
(0.0266)\end{array}$ & $\begin{array}{c}-0.0834 * * * \\
(0.0229)\end{array}$ \\
\hline
\end{tabular}

Source: Authors computations using THS 2008, 2010, 2012 and 2014.

Notes: Standard errors are clustered by birth year and are given in the parenthesis under the coefficients. $* * *, * *$ and $*$ indicate significance at 1,5 and 10 percent levels. 
Table 8: Tobit Estimation Results for Days Hospitalized by Type of Chronic Diseases, 20082014, Turkey

\begin{tabular}{lccc}
\hline Days Hospitalized & $\begin{array}{c}\text { (tobit) } \\
\text { Lung diseases }\end{array}$ & $\begin{array}{c}\text { (tobit) } \\
\text { Heart diseases }\end{array}$ & $\begin{array}{c}\text { (tobit) } \\
\text { Bone diseases }\end{array}$ \\
\hline $\begin{array}{lccc}\text { Sample of 1945-1965 } \\
\text { Years of Education }\end{array}$ & $-0.699 * *$ & $-0.453 * * *$ & $-0.349 * * *$ \\
& $(0.273)$ & $(0.112)$ & $(0.118)$ \\
Number of Obs. & 1,286 & 3,148 & 4,088 \\
Sample of 1980-1990 Cohort & $-0.281^{* *}$ & & \\
Years of Education & $(0.134)$ & -0.0900 & -0.0308 \\
& 468 & $(0.224)$ & $(0.0810)$ \\
Number of Obs. & 309 & 1,294 \\
\hline
\end{tabular}

Source: Author's computations using THS 2008, 2010, 2012 and 2014 waves.

Notes: Standard errors are clustered by birth year and are given in the parenthesis under the coefficients. $* * *, * *$ and $*$ indicate significance at 1,5 and 10 percent levels. Each of the regressions includes a constant, age, age squared and a time trend with its square and cube and dummies for NUTS2 26 regions of residence. These are not reported for brevity. 
Table 9: Double Hurdle Estimation Results by Gender, 2008-2014, Turkey

\begin{tabular}{|c|c|c|c|c|}
\hline \multirow[b]{2}{*}{ Days Hospitalized } & \multicolumn{2}{|c|}{ Female } & \multicolumn{2}{|c|}{ Male } \\
\hline & (Participation) & (Intensity) & (Participation) & (Intensity) \\
\hline \multicolumn{5}{|l|}{ Total } \\
\hline Years of Education & $\begin{array}{c}-0.016^{* * * *} \\
(0.002)\end{array}$ & $\begin{array}{c}-35.628 * * * \\
\quad(8.292)\end{array}$ & $\begin{array}{c}-0.013^{* * *} * \\
(0.003)\end{array}$ & $\begin{array}{c}-105.216^{* * *} \\
(21.333)\end{array}$ \\
\hline Wald chi2 & & 2210.56 & & 1780.42 \\
\hline Log likelihood & & -19031.78 & & -12355.89 \\
\hline Number of Obs. & & 22865 & & 18822 \\
\hline \multicolumn{5}{|l|}{ Sample of 1945-1965 Cohort } \\
\hline Years of Education & $\begin{array}{c}-0.028 * * * \\
(0.006)\end{array}$ & $\begin{array}{c}-91.482 * * \\
(42.820)\end{array}$ & $\begin{array}{l}-0.0066 \\
(0.006)\end{array}$ & $\begin{array}{c}-87.907 * * * \\
(23.315)\end{array}$ \\
\hline \multicolumn{5}{|l|}{ Wald chi2 } \\
\hline Log likelihood & & -4818.98 & & -3908.48 \\
\hline Number of Obs. & & 5514 & & 4906 \\
\hline \multicolumn{5}{|l|}{ Sample of 1980-1990 Cohort } \\
\hline Years of Education & $\begin{array}{c}-0.012 * * \\
(0.005)\end{array}$ & $\begin{array}{c}-32.486 * * \\
(14.750)\end{array}$ & $\begin{array}{l}-0.007 \\
(0.008)\end{array}$ & $\begin{array}{c}-16.025^{* *} \\
(7.246)\end{array}$ \\
\hline Wald chi2 & & 491.09 & & 316.09 \\
\hline Log likelihood & & -4378.29 & & -1767.82 \\
\hline \multirow[t]{2}{*}{ Number of Obs. } & & 5104 & & 3734 \\
\hline & \multicolumn{2}{|c|}{ Female } & \multicolumn{2}{|c|}{ Male } \\
\hline Days out of Work & (Participation) & (Intensity) & (Participation) & (Intensity) \\
\hline \multicolumn{5}{|l|}{ Total } \\
\hline Years of Education & $\begin{array}{c}0.061 * * * \\
(0.003)\end{array}$ & $\begin{array}{c}-75.523 * * \\
(35.245)\end{array}$ & $\begin{array}{c}-0.008 * * \\
(0.003)\end{array}$ & $\begin{array}{c}-345.447 * * \\
(156.807)\end{array}$ \\
\hline Wald chi2 & & 1333.88 & & 2140.95 \\
\hline Log likelihood & & -7488.51 & & -16839.54 \\
\hline Number of Obs. & & 20936 & & 17567 \\
\hline \multicolumn{5}{|l|}{ Sample of 1945-1965 Cohort } \\
\hline Years of Education & $\begin{array}{c}0.0442 * * * \\
(0.009)\end{array}$ & $\begin{array}{c}-3.535 \\
(15.056)\end{array}$ & $\begin{array}{l}-0.001 \\
(0.006)\end{array}$ & $\begin{array}{l}-47.437 \\
(29.061)\end{array}$ \\
\hline Wald chi2 & & 155.49 & & 277.49 \\
\hline Log likelihood & & -1207.49 & & -3653.68 \\
\hline Number of Obs. & & 5002 & & 4320 \\
\hline \multicolumn{5}{|l|}{ Sample of 1980-1990 Cohort } \\
\hline Years of Education & $\begin{array}{c}0.0838 * * * \\
(0.007)\end{array}$ & $\begin{array}{c}-23.952 * * \\
(9.957)\end{array}$ & $\begin{array}{l}-0.008 \\
(0.007)\end{array}$ & $\begin{array}{c}-173.14 * * \\
(81.348)\end{array}$ \\
\hline Wald chi2 & & 401.24 & & 584.69 \\
\hline Log likelihood & & -2102.63 & & -3997.3069 \\
\hline Number of Obs. & & 4631 & & 3644 \\
\hline
\end{tabular}

Source: Authors computations using THS 2008, 2010, 2012 and 2014.

Notes: Standard errors are given in the parenthesis under the coefficients. ***, **and * indicate significance at 1,5 and 10 percent levels. Each of the regressions includes a constant, age, age squared and a time trend with its square and cube and dummies for NUTS2 26 regions of residence. These are not reported for brevity. 
Table 10: Marginal Effects from Double Hurdle Estimation Results by Gender, 2008-2014,

\begin{tabular}{|c|c|c|c|c|c|c|}
\hline \multirow[b]{2}{*}{$\begin{array}{l}\text { Days } \\
\text { Hospitalized }\end{array}$} & \multicolumn{3}{|c|}{ Female } & \multicolumn{3}{|c|}{ Male } \\
\hline & $\begin{array}{c}\text { Average } \\
\text { marginal } \\
\text { effects } \\
\text { on } \\
\text { conditional } \\
\text { outcome }\end{array}$ & $\begin{array}{c}\text { Average } \\
\text { marginal } \\
\text { effects } \\
\text { on the } \\
\text { unconditional } \\
\text { outcome }\end{array}$ & $\begin{array}{l}\text { Average } \\
\text { marginal } \\
\text { effects } \\
\text { on the } \\
\text { probability } \\
\text { of } p>0\end{array}$ & $\begin{array}{c}\text { Average } \\
\text { marginal } \\
\text { effects } \\
\text { on } \\
\text { conditional } \\
\text { outcome }\end{array}$ & $\begin{array}{c}\text { Average } \\
\text { marginal } \\
\text { effects } \\
\text { on the } \\
\text { unconditional } \\
\text { outcome }\end{array}$ & $\begin{array}{c}\text { Average } \\
\text { marginal } \\
\text { effects } \\
\text { on the } \\
\text { probability } \\
\text { of } p>0\end{array}$ \\
\hline $\begin{array}{l}\text { Total } \\
\text { Years of } \\
\text { Education }\end{array}$ & $\begin{array}{l}-0.144 * * * \\
(0.0434)\end{array}$ & $\begin{array}{l}-0.061 * * * \\
(0.0125)\end{array}$ & $\begin{array}{l}-0.004 * * * \\
(0.0006)\end{array}$ & $\begin{array}{l}-0.583 * * * \\
(0.1712)\end{array}$ & $\begin{array}{l}-0.163 * * * \\
(0.0492)\end{array}$ & $\begin{array}{r}-0.002 * * * \\
(0.0006)\end{array}$ \\
\hline $\begin{array}{l}\text { Sample of } 19 \\
\text { Cohort } \\
\text { Years of } \\
\text { Education }\end{array}$ & $\begin{array}{l}-0.373 * * \\
(0.1846)\end{array}$ & $\begin{array}{l}-0.163 * * \\
(0.0806)\end{array}$ & $\begin{array}{l}-0.007 * * * \\
(0.0015)\end{array}$ & $\begin{array}{l}-1.248^{*} \\
(0.6173)\end{array}$ & $\begin{array}{l}-0.301 \\
(0.2566)\end{array}$ & $\begin{array}{l}-0.002 \\
(0.0015)\end{array}$ \\
\hline $\begin{array}{l}\text { Sample of } 19 \\
\text { Cohort } \\
\text { Years of } \\
\text { Education }\end{array}$ & $\begin{array}{l}-0.092 * \\
(0.0515)\end{array}$ & $\begin{array}{l}-0.033 * * \\
(0.0132)\end{array}$ & $\begin{array}{l}-0.003 * * * \\
(0.001)\end{array}$ & $\begin{array}{l}-0.476 \\
(0.3803)\end{array}$ & $\begin{array}{l}-0.072 * \\
(0.0391)\end{array}$ & $\begin{array}{r}-0.003 * * \\
(0.012)\end{array}$ \\
\hline $\begin{array}{l}\text { Days out of } \\
\text { Work }\end{array}$ & $\begin{array}{c}\mathrm{F} \\
\text { Average } \\
\text { marginal } \\
\text { effects } \\
\text { on } \\
\text { conditional } \\
\text { outcome }\end{array}$ & $\begin{array}{c}\text { male } \\
\text { Average } \\
\text { marginal } \\
\text { effects } \\
\text { on the } \\
\text { unconditional } \\
\text { outcome } \\
\end{array}$ & $\begin{array}{c}\text { Average } \\
\text { marginal } \\
\text { effects } \\
\text { on the } \\
\text { probability } \\
\text { of } p>0\end{array}$ & $\begin{array}{c} \\
\text { Average } \\
\text { marginal } \\
\text { effects } \\
\text { on } \\
\text { conditional } \\
\text { outcome }\end{array}$ & $\begin{array}{c}\text { Aale } \\
\text { Average } \\
\text { marginal } \\
\text { effects } \\
\text { on the } \\
\text { unconditional } \\
\text { outcome } \\
\end{array}$ & $\begin{array}{l}\text { Average } \\
\text { marginal } \\
\text { effects } \\
\text { on the } \\
\text { probability } \\
\text { of } p>0\end{array}$ \\
\hline $\begin{array}{l}\text { Total } \\
\text { Years of } \\
\text { Education }\end{array}$ & $\begin{array}{l}-0.618 * \\
(0.3341)\end{array}$ & $\begin{array}{l}0.065^{* * *} \\
(0.0119)\end{array}$ & $\begin{array}{l}0.006 * * * \\
(0.0003)\end{array}$ & $\begin{array}{l}-1.518 * * * \\
(0.5046)\end{array}$ & $\begin{array}{l}-0.231 * * * \\
(0.0499)\end{array}$ & $\begin{array}{l}-0.001 * * * \\
(0.0006)\end{array}$ \\
\hline $\begin{array}{l}\text { Sample of } 19 \\
\text { Cohort } \\
\text { Years of } \\
\text { Education }\end{array}$ & $\begin{array}{l}-0.118 \\
(0.5251)\end{array}$ & $\begin{array}{l}0.048 * * * \\
(0.01824)\end{array}$ & $\begin{array}{l}0.002 * * * \\
(0.0007)\end{array}$ & $\begin{array}{l}-1.559 \\
(1.4860)\end{array}$ & $\begin{array}{l}-0.149 \\
(0.1370)\end{array}$ & $\begin{array}{l}-0.0001 \\
(0.0011)\end{array}$ \\
\hline $\begin{array}{l}\text { Sample of } 19 \\
\text { Cohort } \\
\text { Years of } \\
\text { Education }\end{array}$ & $\begin{array}{l}-0.801 * \\
(0.4038)\end{array}$ & $\begin{array}{l}0.080 * * * \\
(0.0265)\end{array}$ & $\begin{array}{l}0.009 * * * \\
(0.0009)\end{array}$ & $\begin{array}{l}-0.895 \\
(0.6173)\end{array}$ & $\begin{array}{c}-0.183 * * \\
(0.0919)\end{array}$ & $\begin{array}{l}-0.002 \\
(0.0015)\end{array}$ \\
\hline
\end{tabular}

Source: Authors computations using THS 2008, 2010, 2012 and 2014.

Notes: Bootstrap standard errors (100-replications) are given in the parenthesis under the coefficients. $* * *, * *$ and $*$ indicate significance at 1, 5 and 10 percent levels. 